\title{
Serotonin Receptors in Hippocampus
}

\author{
Laura Cristina Berumen, ${ }^{1}$ Angelina Rodríguez, ${ }^{1}$ Ricardo Miledi, ${ }^{2,3}$ \\ and Guadalupe García-Alcocer ${ }^{1}$ \\ ${ }^{1}$ Facultad de Química, Universidad Autónoma de Querétaro, Centro Universitario S/N, Cerro de las Campanas, \\ Querétaro 76010, Mexico \\ ${ }^{2}$ Instituto de Neurobiología, Universidad Nacional de México, Campus Juriquilla, Querétaro 76230, Mexico \\ ${ }^{3}$ Department of Neurobiology and Behaviour, University of California, Irvine, CA 92697-4550, USA
}

Correspondence should be addressed to Guadalupe García-Alcocer, leguga@email.com

Received 27 October 2011; Accepted 8 December 2011

Academic Editor: Jerrel Yakel

Copyright () 2012 Laura Cristina Berumen et al. This is an open access article distributed under the Creative Commons Attribution License, which permits unrestricted use, distribution, and reproduction in any medium, provided the original work is properly cited.

\begin{abstract}
Serotonin is an ancient molecular signal and a recognized neurotransmitter brainwide distributed with particular presence in hippocampus. Almost all serotonin receptor subtypes are expressed in hippocampus, which implicates an intricate modulating system, considering that they can be localized as autosynaptic, presynaptic, and postsynaptic receptors, even colocalized within the same cell and being target of homo- and heterodimerization. Neurons and glia, including immune cells, integrate a functional network that uses several serotonin receptors to regulate their roles in this particular part of the limbic system.
\end{abstract}

\section{Serotonin}

Serotonin (5-hydroxytryptamine; 5-HT), named by Rapport et al. (1948) [1], is one of the ubiquitous molecules acting as messengers, well known as a neurotransmitter and neuromodulator. Serotonin (Figure 1) is mostly found outside the central nervous system [2]; it was first identified in enterochromaffin cells and named as "enteramine" by Vialli and Erspamer in 1937 and confirmed to be the same entity with the "clotted blood" vasoconstriction effects in 1952 [3].

\section{Serotonin as an Ancient Molecular Signal}

The serotonergic system is an ancient sensor of diverse stimuli and molecular signaling in single-celled eukaryotes, plants, and animals [4-6].

The regulated expression of genetic material in every cell is very important and a "regulatory lesson" learned over the years is that small metabolites are often regulatory signals to control gene expression. For "expensive" biosynthesis, as the required for the serotonin precursor tryptophan, common pathways are found in organisms that take advantage of the aromatic structures; tryptophan serves as the precursor not only of serotonin (Figure 2), but also of very important compounds as niacin in eukaryotes, indoleacetic acid in plants, and indole in bacteria. Regulatory strategies could be compatible with other metabolic goals as organisms evolved capable of obtaining tryptophan by feeding, with specific plasma membrane transporters $[7,8]$.

Beyond the heterotrophic theory of the very first living organisms [9], serotonin could be used as specific signal, after direct relation with tryptophan synthesis was controlled, and specific monoamine transporters that do not need the missing carboxyl group of the aminoacids [7, 10] were present; later, it acquired functions of "hormone" and growth factor, and serotonin activity as neurotransmitter was achieved at last [4]. In prenervous stages, serotonin regulates basic developmental processes from cleavage divisions after fertilization (proliferator) to morphogenetic cell movements during gastrulation (morphogen) in sea urchin [11]. Presence of serotonin and its metabolite 5-hydroxyindoleacetic acid in unicellular ciliate Tetrahymena pyriformis [12] and increasing RNA production in the 5-HT stimulated protozoa [13] suggested an active biogenic amine system with relevant functions; interaction with GTPases might represent some 


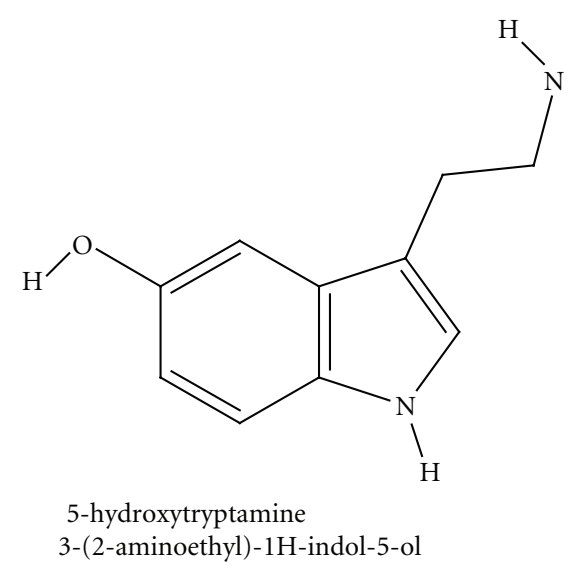

Figure 1: Serotonin (5-HT). Modified image from NCBI PubChem Substance Database CID 5202.

of the earlier functions of serotonin (and biogenic amines) before it could be vesiculated and its exocytosis could be regulated for metazoan serotonergic systems $[14,15]$.

\section{Serotonin as a Regulatory Molecule in Animals}

This happy hormone, as recalled by Dr. Barnes [16], plays a modulatory role in almost every physiological function and is involved in many biological processes [2, 17]; furthermore, the three related metabolites, 5HT, tryptophan, and melatonin, are important regulators of feed intake, reproduction, immunity, neurological function, and antistress responses [18].

Serotonin is involved in natural reward-related physiology and behaviour, from feeding to sexual activity [19] with many actions correlated to the involved location (cellulartissue-organ concentration) and the different signaling can also be associated with its more than fourteen receptor subtypes, regulating physiological processes through different, even opposing mechanisms; these indoleamine effects include also serotonylation and interaction with GTPases $[2,14,15]$. Serotonin influences body temperature, breathing rhythms (respiratory system), heart rate (cardiovascular function in general), eating and bowel motility (gastrointestinal system), ejaculatory latency and bladder control, muscle contraction/relaxation and locomotion, sleep, arousal, pain and sensory perception, emotions, and cognition $[2,5,20]$ with a well-known signaling role in immune cells [21].

\section{Serotonin in Central Nervous System}

Serotonergic neurons, first discovered in the brainstem by Dahlström and Fuxe in 1964 [22], release 5-HT throughout the CNS $[23,24]$ as expected after the brain serotonin discovery [25]. 5-HT cell bodies are mainly localized in the raphe nuclei with their axons innervating almost every brain region [17]. The hippocampus is a principal target of serotonergic afferents along with all the limbic system [26]. The serotonin

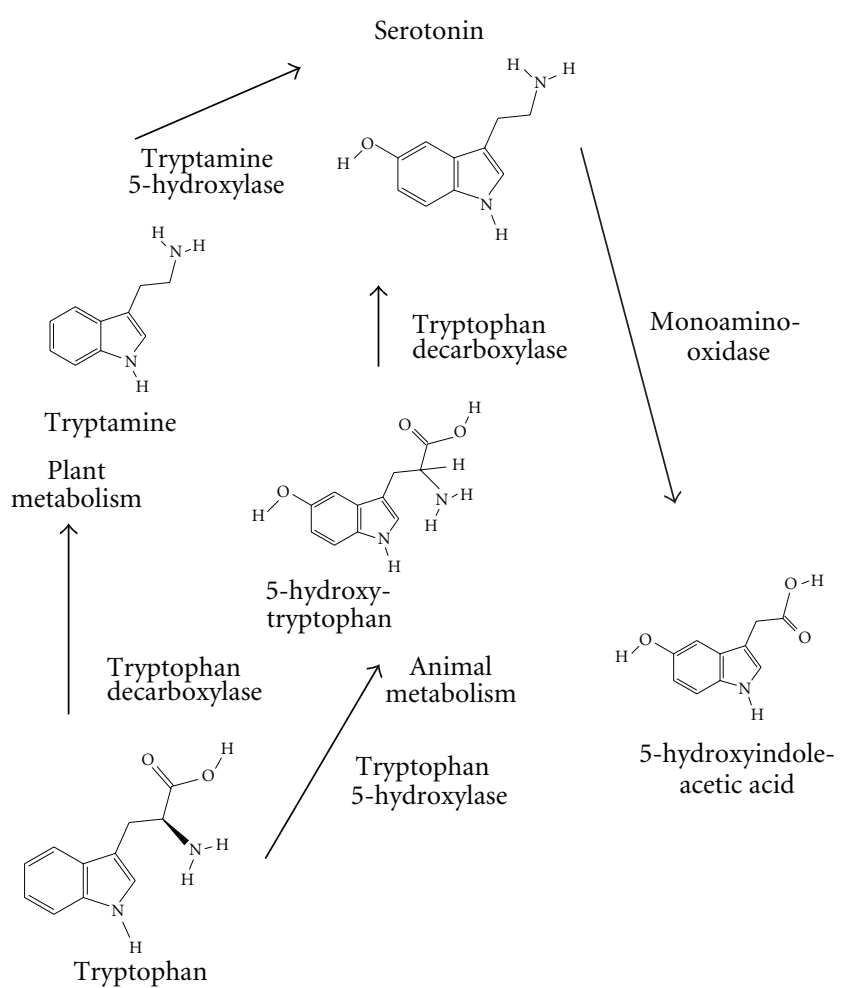

FIGURE 2: Serotonin metabolism. Tryptophan is the precursor for serotonin synthesis, with different enzymatic reactions in plant and animals [6]; hydroxylation is the rate limiting step (enzyme mediated by tryptophan hydroxylase in animals or tryptamine hydroxylase in plants), while decarboxylation is a rapid conversion by the aromatic amino acid decarboxylase (tryptophan decarboxylase). The catabolic metabolite of serotonin is 5-hydroxyindoleacetic acid, via 5-hydroxyindole acetaldehyde enzymatically converted by the membrane-bound mitochondrial flavoprotein monoamino oxidase. Modified images from NCBI PubChem Substance Database.

projections to hippocampus stem in a topographic order from the midbrain dorsal and median raphe nuclei [2729]. The rat ventral hippocampus receive moderately dense projections from the caudal dorsal raphe and essentially none from the rostral dorsal raphe, with fine serotonergic axons and small varicosities widely distributed throughout the hippocampus. Furthermore, beaded serotonergic axons with large, spherical varicosities are also found in hippocampus; median raphe nucleus predominantly innervate the stratum lacunosum moleculare of the $\mathrm{CA} 1$ and $\mathrm{CA} 3$ regions and the dentate hilus $[26,28,30,31]$. The density of serotonergic axons is highest in CA3, lower in dentate gyrus and lowest in CA1 $[26,30]$. Almost all subtypes of serotonin receptors are expressed in hippocampus during ontogeny, so the regulation of the serotonergic system is more than complex $[32,33]$.

\section{Serotonin Receptors}

Heterogeneity in serotonin receptors was established by the late 1950s, with Gaddum and Picarelli [34] proposing two tryptamine receptors in the guinea-pig ileum: $M$ and 


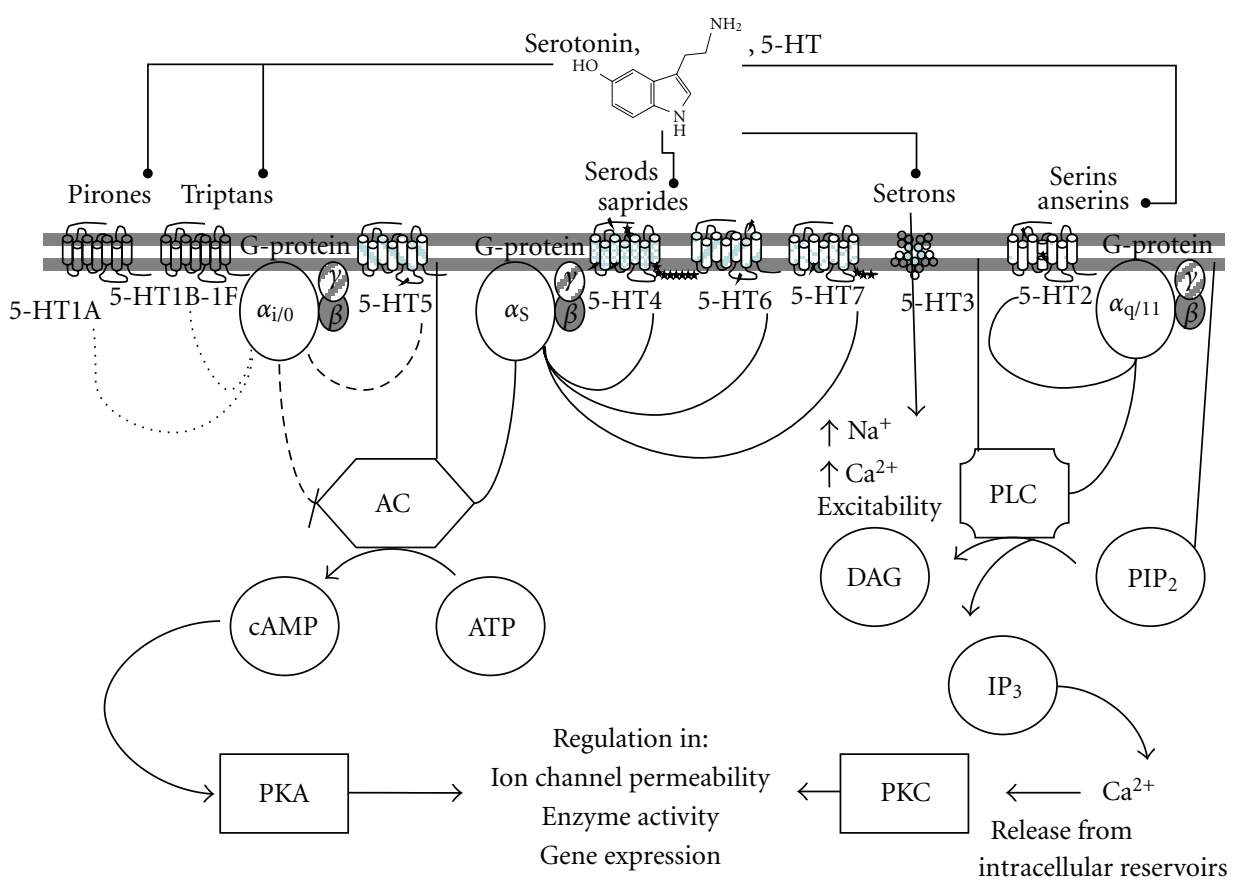

FIGURE 3: Serotonin main signaling pathways. 5-HT or agonists/antagonists for each receptor $(\bullet)$ interact in the extracellular side and the conformational changes of 5-HTRs modify the activity of specific intracellular enzymes, which in time modify other targets state to provoke different cellular responses [43]. G-protein $\beta \gamma$ pathways are not represented in the figure. All of the serotonin receptor subtypes are represented for a hippocampal pyramidal cell, as reported, but subpopulations of these neurons might differentially express 5-HT receptors. AC, adenylate cyclase; PLC, phospholipase C. The 7TMD images of each subtype receptor are represented with the defined number of exons that code for the mature protein [44]; putative intron location in correspondent pre-mRNA is marked by a lightning symbol ( $\{$ ), and alternative splicing sites are marked with stars $(\star \star \star)$.

$\mathrm{D}$, blocked with morphine and dibenzyline, respectively; binding to serotonin receptors was also studied with $\left[{ }^{3} \mathrm{H}\right]$ $5-\mathrm{HT}$ and $\left[{ }^{3} \mathrm{H}\right]$ LSD $[35,36]$ and more than twenty years later a new classification was proposed by Peroutka and Snyder (1979): 5-HT1 and 5-HT2 receptors based on radioligand binding techniques $\left(\left[{ }^{3} \mathrm{H}\right] 5-\mathrm{HT},\left[{ }^{3} \mathrm{H}\right]\right.$ LSD and $\left[{ }^{3} \mathrm{H}\right]$ spiroperidol) [37].

With the use of specific radiolabelled ligands, there was a new classification [38] proposing 5-HT3 receptors although 5-HT1-like receptors were still considered a heterogeneous entity. Others tried to adjust the new information and finally, with the advances in molecular biology, the serotonin receptors were cloned, finding more than three subtypes. The Serotonin Club Receptor Nomenclature Committee (SCRNC), reporting directly to the IUPHAR Committee for Receptor Nomenclature, described a new classification of 5-HT receptors [39]. This classification was based in different operational (selective agonists, antagonists, and ligand-binding affinities), structural (molecular structure), and transductional (intracellular transduction mechanisms) criteria.

Serotonergic receptors (Figure 3 ) were grouped in seven classes $5-\mathrm{HT}_{1-7}$, all of them belonging to the G-proteincoupled receptor (GPCR) superfamily [40], except 5- $\mathrm{HT}_{3}$ which is a ligand-gated ion channel that belongs to the nicotinic acetylcholine receptor superfamily: cystein-loop transmitter gated superfamily which constitutes heteropentamers
$[5,41,42]$. Particularly, subindex for the different receptors were arranged and the former 5-HT1C was renamed as $5-\mathrm{HT}_{2 \mathrm{C}}$, for its transductional properties and molecular structure [39]. In the paper, subscript will be used for 5-HT subtype receptors after SCRNC, and normal line of type for previous findings in subtype receptor will be written.

\section{Ion Channel Serotonin Receptor}

The $5-\mathrm{HT}_{3}$ receptor is a cation-selective ion channel which activation evokes neuronal excitation and neurotransmitter release. There are two well-recognized genes encoding $\mathrm{A}$ and $\mathrm{B}$ subunits, but additional $\mathrm{C}, \mathrm{D}$, and $\mathrm{E}$ genes expand the diversity to heterooligomer formation of the pentameric channel [45]. The different composition might reflect distinct pharmacology and relevance to their function representing each one a different subtype of receptor. These subunits can interact with other members of the Cys-loop superfamily, regarding the previous " $M$ "-type serotonin of Gaddum and Picarrelli classification [46].

\section{Metabotropic Serotonin Receptors}

The seven transmembrane domain (7TMD) serotonin receptors belong to the "type A" family of GPCR, rhodopsin-like receptors, grouped by Fredricksson et al. (2003) in the amine 


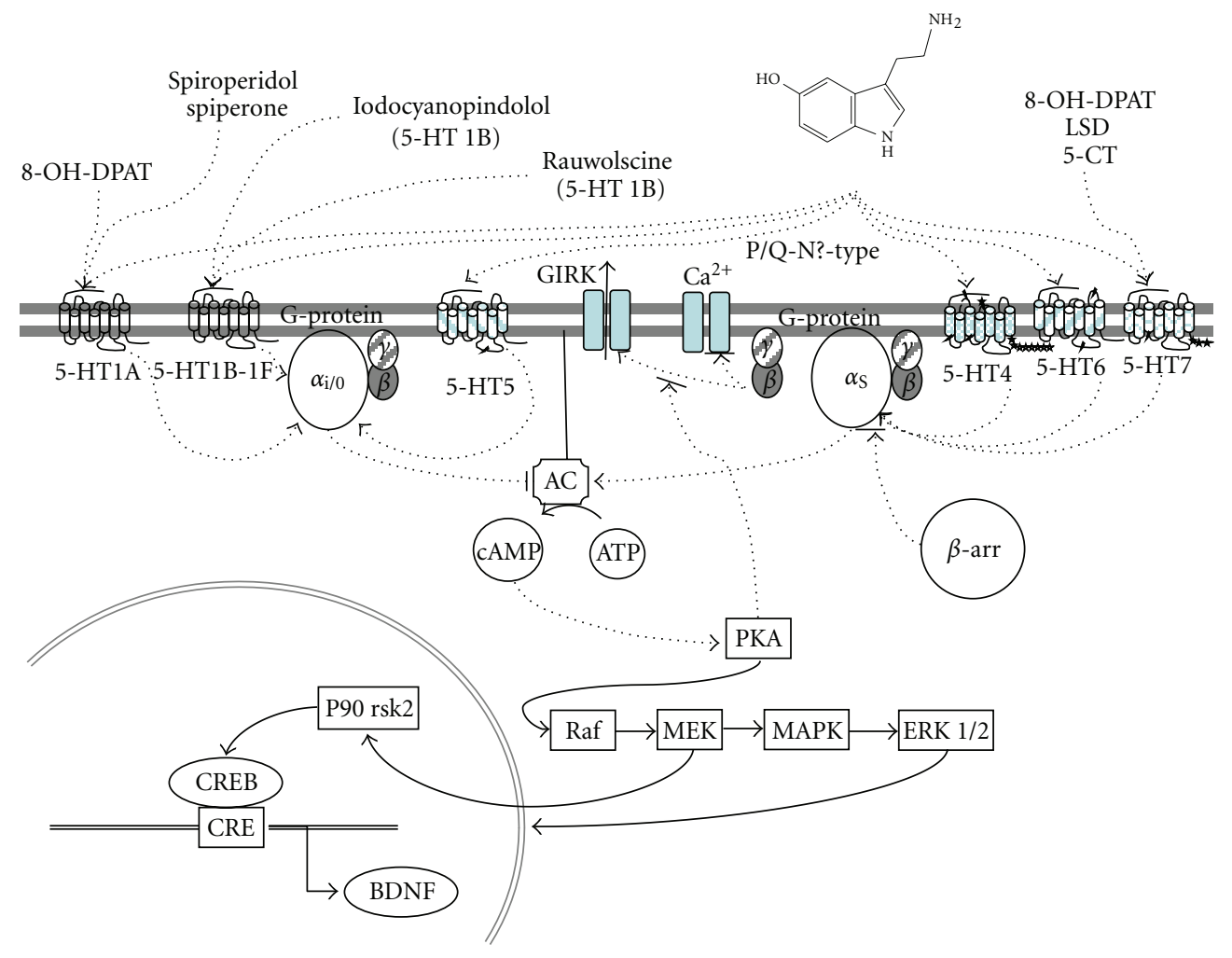

FIGURE 4: cAMP signaling pathways. Serotonin receptors 5- $\mathrm{HT}_{1}$ and 5- $\mathrm{HT}_{5}$ interact with $\alpha_{\mathrm{i} / 0}$ G-protein inhibiting the formation of cyclic adenylate monophosphate (cAMP) by adenylate cyclase (AC), while $5-\mathrm{HT}_{4}, 5-\mathrm{HT}_{6}$, and 5-HT $\mathrm{HT}_{7}$ activate AC by means of $\alpha_{\mathrm{S}} \mathrm{G}-$ protein. $\beta \gamma$ subunits of G-protein may interact in other signaling pathways, for example, modulating GIRK or calcium voltage gated channels. Representation of $\beta$-arrestin ( $\beta$-arr) is made to indicate other signaling pathways. Traditional ligands to study different subtype receptors are written in the extracellular zone; note that $5-\mathrm{HT}_{7}$ may bind the traditional ligand for 5- $\mathrm{HT}_{1 \mathrm{~A}}$ as well as $\mathrm{LSD}$ (5-HT $\mathrm{HT}_{2}$ ligand).

receptor cluster [47]. They display a heterogeneous phylogenetic pattern with $5-\mathrm{HT}_{2}$ forming one group and $5-\mathrm{HT}_{1 \mathrm{~B}-1 \mathrm{~F}}$ forming another group; the rest of 5-HT receptor subtypes can be related with other biogenic amine receptors clusters. In other classification [48], 7TMD 5-HT receptors can be grouped in type 1 family that contains GPCRs for small ligands binding in a cavity formed by TM-III to TM VI [49].

The 7TMD serotonin receptors are coupled to different $G$ proteins. The $5-\mathrm{HT}_{1}$ receptors couple to $\mathrm{G} \alpha_{\mathrm{i}} / \mathrm{G} \alpha_{0}$ proteins; the $5-\mathrm{HT}_{2}$ receptors couple to $\mathrm{G} \alpha_{\mathrm{q}}$ proteins; the $5-\mathrm{HT}_{4}, 5-$ $\mathrm{HT}_{6}$ and $5-\mathrm{HT}_{7}$ receptors couple to $\mathrm{G} \alpha_{\mathrm{s}}$ proteins, and the 5$\mathrm{HT}_{5}$ receptors are related to $\mathrm{G} \alpha_{\mathrm{i}} / \mathrm{G} \alpha_{\mathrm{o}}$ proteins [44].

Activation of $\mathrm{G} \alpha_{\mathrm{s}}$ coupled receptors (Figure 4) leads to the stimulation of adenylyl cyclases elevating cyclic AMP (cAMP), which as a second messenger interacts with other proteins including ion channels and activating the protein kinase A (PKA). This phosphorylating enzyme also activates cAMP-responsive transcription factors like CREB modifying gene expression. The interaction with other exchange proteins directly activated by cAMP leads to alternative signaling cascades besides the classical PKA. The interaction with $\mathrm{G} \alpha \alpha_{\mathrm{i}}$ leads to inhibition of adenylyl cyclases, decreasing production of cAMP [5].
The activation of $\mathrm{G} \alpha_{\mathrm{q} / 11}$ coupled receptors (Figure 5) lead to the hydrolysis of membrane phosphoinositides resulting in the formation of diacyl glycerol (DAG) and inositol phosphates $\left(\mathrm{IP}_{3}\right) . \mathrm{IP}_{3}$ can interact with the calcium reservoirs, elevating intracellular levels and activating protein kinase C $[5,50]$. Serotonin receptors may also be coupled to $\mathrm{G} \alpha_{12 / 13}$, mediating structural changes within the cell through activation of the Rho signaling pathway [41].

The $\mathrm{G}_{\beta \gamma}$ dimeric subunit can interact with a variety of enzymatic effectors within the cell, like their action on gated ion channels, regulation of particular isoforms of adenylyl cyclase and phospholipase $\mathrm{C}$, and phosphoinositide-3-kinase isoforms (and ERK signaling) [51].

If so many receptor subtypes of serotonin make it complex to understand, plethora of activities can be found with the coupling to multiple G-proteins. There are different parameters in the activation pathway of the GPCR receptors, considering multiple states instead of the traditional twostate model of activation and forming dimers that may have distinct pharmacology with respect to activation, signaling, and internalization and the organization in microdomains at the membrane level that may affect coupling and trafficking of G-proteins [52]. 


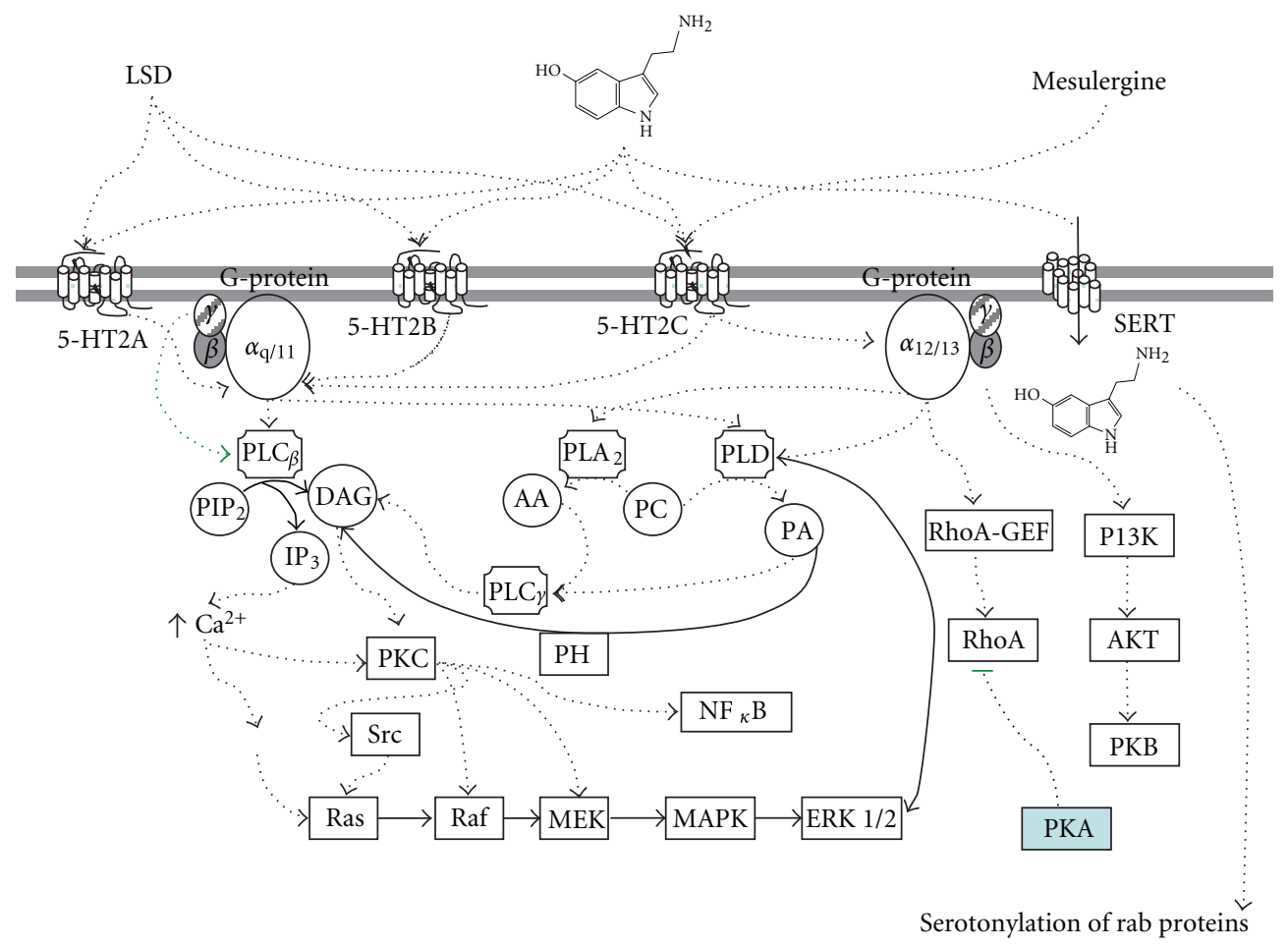

FIgURE 5: 5- $\mathrm{HT}_{2}$ receptors signaling. Main pathways of intracellular signaling for these serotonine receptors subtype involve rupture of membrane phospholipids, particularly with phospholipase C (PLC) producing diacylglycerol (DAG) and inositol 1,4,5-trisphosphate (IP ${ }_{3}$ ) from phosphatidylinositol 4,5-bisphosphate $\left(\mathrm{PIP}_{2}\right)$. These second messengers activate protein kinase $\mathrm{C}(\mathrm{PKC})$ which in time may activate the extracellular signal-regulated kinases 1 and 2 (ERK1/2) [50]. Phospholipase A2 is eventually activated producing arachidonic acid (AA) from phosphatidylcholine (PC), or phosphatidic acid (PA) by means of phospholipase D (PLD) [44, 50]. SERT is included in the diagram, coexisting in astrocytes for example, to emphasize the intracellular participation of serotonin itself [14]. Other pathways including (Rho$\mathrm{GEF}$ ) and (PI3K) are shown [51]. MEK, mitogen-activated protein kinase; PH, phosphohydrolase enzyme; PKA, protein kinase A-relation to cAMP pathways; SERT, serotonin transporter.

Promiscuous coupling of GPCRs to G-proteins is not a surprise, and they can also signal without coupling to them; they can activate a variety of cascades by arrestin-ergic signalling, beside the original function of these proteins in terminating coupling and endocytosis $[53,54]$.

In brief, there are thirteen genes coding for GPCR serotonin receptors that may couple almost every G-protein in the cell membrane and probably act without coupling to them, and two recognized genes coding for the subunits of cation-selective $5-\mathrm{HT}_{3}$ ligand-gated ion channel pentameric receptor.

This diversity is further complexed by the posttranslational and co/posttransductional modifications of the protein to be produced, without talking about oligomerization of the serotonin receptors and single-nucleotide polymorphisms. There are examples of this modifications in the different receptor families with alternative splicing, RNA editing, palmitoylation, glycosylation, phosphorylation, and proteolysis, to mention a few [55].

\section{Serotonin Receptors Expression in Hippocampus}

All the serotonin receptor families are remarkably expressed in hippocampus, which is part of the limbic system, a whole structure related with memory processing, emotional association with memory, judgment, affect, and motivation or the organization of planned actions [26]. The innervation of serotonergic pathways in hippocampus and the diverse expression of serotonin receptors in this brain area reflect the overall functions related to 5-HT, in particular with cognition, mood and food intake. After recognition of hippocampal serotonergic afferents by histochemical methods (fluorescence, potassium dichromate), uptake of tritiated serotonin was achieved corroborating the wide spread of 5-HT pathways [56]. Molecular biology of the specific receptors for serotonin confirmed this knowledge.

8.1. 5-HT 1 Receptors. The hippocampus contains a high density of $5-\mathrm{HT}_{1}$ sites, most of which belong to the $5-\mathrm{HT}_{1 \mathrm{~A}}$ subtype [39]. Before classification of serotonin receptors on the basis of their molecular biology, distinction between the receptors in this group was based on the affinities for 8-hydroxy-2-(di-n-propylamino)tetralin (8-OH-DPAT) distinguishing 5-HT1A, lysergic acid diethylamide (LSD) and mesulergine detecting 5-HT1C, later renamed as 5HT2C, and rauwolscine for 5-HT1D receptors, for example, but findings of new receptors with affinity for these ligands may clarify error in quantitation of the former groups. 
8.2. 5- $H T_{1 A}$. Fargin et al. characterized the genomic clone G21 that corresponded to $5-\mathrm{HT}_{1 \mathrm{~A}}$ sequence [57]. Gozlan et al. (1983) [58] had previously reported the existence of 5 HT1like receptors in hippocampus on the basis of the binding experiments of $\left[{ }^{3} \mathrm{H}\right]$ 8-OH-DPAT. In 1986, Hoyer et al. [59] and Vergé et al. [60] confirmed these results and compared binding of 5-HT1A and 5-HT1B; later characterization was performed by chromatographic analyses of the serotonin 5-HT1A receptor solubilized from the rat hippocampus [61]. Activation of somatodendritic autoreceptors diminished 5-HT synaptic transmission [62] suggesting that 5-HT1A might represent presynaptic receptors as well as postsynaptic neurotransmission in hippocampus. At cellular levels, $5-\mathrm{HT}_{1 \mathrm{~A}}$ receptors are located postsynaptically in pyramidal and granular neurons of the hippocampus as well as extrasynaptic structures, by studies using highly selective $5-\mathrm{HT}_{1 \mathrm{~A}}$ antibodies that allowed confirmation and refinement of autoradiographic results [41]. They function as somatodendritic inhibitory receptors in raphe nuclei and presynaptically in hippocampus [63]. 5- $\mathrm{HT}_{1 \mathrm{~A}}$ has also been detected in some astrocytes, radial glia, and ependymal and endothelial cells [64].

8.3. $5-H T_{1 B}$. Molecular cloning of rat $5-\mathrm{HT}_{1 \mathrm{~B}}$ receptor was performed by Voigt et al. in 1991 [65]. Previously, 5HT1B was defined as the nonspiperone sensitive $\left[{ }^{3} \mathrm{H}\right] 5$ HT binding in brain [41]; localization of 5-HT1B was described with low densities in hippocampus (gyrus dentatus $>C A 1 \geq C A 3)$ by affinity differences with $\left[{ }^{3} \mathrm{H}\right]$ 8-OH-DPAT [60] and binding studies with $\left[{ }^{125} \mathrm{I}\right]$ iodocyanopindolol [66]. Immunohistochemistry analysis had also shown coexpression of $5-\mathrm{HT}_{1 \mathrm{~B}}$ in hippocampal cells with other serotonin receptors [67]. 5- $\mathrm{HT}_{1 \mathrm{~B}}$ receptors are responsible for the presynaptic inhibition of neurotransmission at the local synapses between axon collaterals of CA1 pyramidal cells and other CA1 pyramidal neurons and interneurons [68]. Projection neurons from hippocampus reach the bed nucleus of the stria terminalis, where presynaptic $5-\mathrm{HT}_{1 \mathrm{~B}}$ receptors are involved in the inhibition of glutamate transmission [69]. Furthermore, 5- $\mathrm{HT}_{1 \mathrm{~B}}$ hippocampal GABAergic axon terminal heteroreceptors inhibit neurotransmitter release [70].

8.4. 5-HT $T_{1 D}$. Hamblin and Metcalf in 1991 [71] described sequence of human 5-HT1D serotonin receptor and two genes known as 5-HT1Da and 5-HT1Db were reported [72]. It was clear later that $5-\mathrm{HT} 1 \mathrm{Db}$ was the homologue receptor of rat $5-\mathrm{HT} 1 \mathrm{~B}$, so called $5-\mathrm{HT}_{1 \mathrm{~B}}$. Operational profiles between the former 5-HT1Da and 5-HT1Db receptors were almost indistinguishable, and similarities are still very present [41]. 5-HT1Da remained as the homologue of rat $5-\mathrm{HT} 1 \mathrm{D}$, and so-called $5-\mathrm{HT}_{1 \mathrm{D}}$. 5-HT $\mathrm{HT}_{1 \mathrm{D}}$ binding sites resemble those of $5-\mathrm{HT}_{1 \mathrm{~B}}$ receptors in hippocampus with very low presence $[41,73] .5-\mathrm{HT}_{1 \mathrm{~B} / 1 \mathrm{D}}$ receptors are found at pre- and postsynaptic sites but presynaptic receptors are predominantly located on 5-HT hippocampal nerve terminals [63].

8.5. $5-H T_{1 E}$. There is not a clear characterization of $5-\mathrm{HT}_{1 \mathrm{E}}$ due to the lack of specific ligands that might differentiate this receptor subtype; furthermore, expression of $5-\mathrm{HT}_{1 \mathrm{E}}$ has not been found in rodents, because there is a stop codon in the correspondent mRNA [41]. Cloning of this receptor was achieved using cDNA synthesized from monkey cortex and human hippocampal cDNA library [74] though confirming its presence in hippocampus, previously reported by the existence of a 5-HT1E subtype in human brain with findings in radioligand studies [75].

8.6. 5- $H T_{1 F}$. When 5-HT $\mathrm{HF}_{1 \mathrm{~F}}$ was found [76], it was designated as $5-\mathrm{HT}_{1 \mathrm{~Eb}}$ due to its related pharmacological profile; 5$\mathrm{HT}_{1 \mathrm{~F}}$-labeling was moderate in granule cells of the dentate gyrus and hippocampal pyramidal cells in CA1-CA3, confirming its expression in hippocampus [77].

8.7. 5- $\mathrm{HT}_{2}$ Receptors. Receptors from this group were originally recognized by ligands like ketanserin, mesulergine, LSD, and spiperone, which were reported to have high affinities for 5-HT2 receptors compared to 5-HT1 group [78]. These receptors are coupled to phosphatidylinositol hydrolysis although some effects may involve intracellular calcium release via an independent mechanism [79]. Hoyer et al. [80] used Ketanserin binding though localizing 5-HT2 receptors recognition sites in hippocampus.

8.8. $5-H T_{2 A}$. On the basis of the similarity in exerting the cellular effects which reflected the structural relationship with the former 5-HT1C receptor, Pritchett et al. (1988) used oligonucleotides encoding this serotonin receptor and found $5-\mathrm{HT}_{2 \mathrm{~A}}$ sequence [81]. Julius et al. (1990) also found an encoding sequence for 5-HT2 which was expressed in hippocampus in a 10-fold lower level than in rat cortex [82]. The $5-\mathrm{HT}_{2 \mathrm{~A}}$ receptor refers to the classical $\mathrm{D}$ receptor described by Gaddum and Picarelli in 1957 and defined later as 5-HT2 by Peroutka and Snyder in 1979 [37]. 5- $\mathrm{HT}_{2 \mathrm{~A}}$ expression in human hippocampus was confirmed with RTPCR technique [83]. Immunoreactivity for $5-\mathrm{HT}_{2 \mathrm{~A}}$ receptor in hippocampus was found primarily in the pyramidal cell layer of CA1-CA3 and in the granular layer of dentate gyrus [84]. Agonist studies with 1-(2,5-dimethoxy-4-iodophenyl)2-aminopropane (DOI) indicate postsynaptic receptors for $5-\mathrm{HT}_{2 \mathrm{~A}}$ [63]; in prelimbic prefrontal cortex, most $5-\mathrm{HT}_{2 \mathrm{~A}}$ receptors were postsynaptically located, but presynaptic axons and varicosities locations were found [85]. Cellular localization of $5-\mathrm{HT}_{2 \mathrm{~A}}$ receptors in astrocytes has been found in hippocampus [86].

8.9. 5-HT $T_{2 B}$. The "last" 5-HT2-like receptor subtype to be cloned was 5- $\mathrm{HT}_{2 \mathrm{~B}}$ [87] from rat stomach fundus. The origin and comparable sequence to $5-\mathrm{HT} 1 \mathrm{C} / 2$ led them to designate it as 5-HT2F (for fundus) and renamed as $5-\mathrm{HT}_{2 \mathrm{~B}}$ after consensus of SCRNC in 1994. Cloned human $5-\mathrm{HT}_{2 \mathrm{~B}}$ receptors had a high degree of homology with mouse and rat receptors although with higher affinity for ketanserin and a lower affinity for yohimbine; it was found at very low presence in the whole brain [88]. Expression of 5$\mathrm{HT}_{2 \mathrm{~B}}$ receptors in cultured astrocytes from hippocampus with $\mathrm{Ca}^{2+}$ increases after stimulation with alpha-methyl 5HT has been reported [89]. The presence of this receptor in astrocytes was verified with immunohistochemistry and 
westernblot analysis. Furthermore, microglial cell cultures expresses $5-\mathrm{HT}_{2 \mathrm{~B}}$ receptors, and they are involved in the regulation of inflammatory cytokine production from blood cells [90].

8.10. 5-HT 2 . Lübbert and colleagues cloned in 1987 [91] the mouse 5-HT1C-mRNA (actually 5- $\mathrm{HT}_{2 \mathrm{C}}$ ) extracted from choroid plexus tumors; Julius et al. (1988) characterized a cDNA encoding this protein and confirmed the receptor expression in neurons of many regions of central nervous system by in situ hybridization and RNA blot analysis [92]. It was first identified in porcine choroid plexus on the basis of its pharmacological properties [93] and localized by autoradiographic mapping in rat [94] and human brain, particularly in hippocampus [80].

The overall distribution of $5-\mathrm{HT}_{2 \mathrm{C}}$ receptor was reported by several studies with mRNA in situ hybridization [95-98]. The specificity of radioligand binding $\left(\left[{ }^{3} \mathrm{H}\right]\right.$ mesulergine) was compared with in situ hybridization by Mengod et al. (1990), finding high signal in the pyramidal layer of the CA3 field of rostral rodent hippocampal formation, while intense hybridization was found in the strata oriens and radiatum of the caudal CA1 area and in the ventral subiculum [97]. Furthermore, Abramowski et al. (1995) compared $\left[{ }^{3} \mathrm{H}\right]$ mesulergine binding with specific antibodybinding in rat and human brain [99]; Clemett et al. (2000) also studied the presence of $5-\mathrm{HT}_{2} \mathrm{C}$ protein with immunohistochemistry and western blotting with abundant expression in rat hippocampus [100].

8.11. 5-HT $\mathrm{T}_{3}$ Receptors. $5-\mathrm{HT}_{3}$ receptor belongs to the ligandgated ion channel superfamily and corresponds to the $\mathrm{M}$ receptor of Gaddum and Picarelli [41, 101]; five subunits have been cloned although only $5-\mathrm{HT}_{3 \mathrm{~A}}$ and $5-\mathrm{HT}_{3 \mathrm{~B}}$ are recognized for rodents [102-106]. The various subtypes of 5 - $\mathrm{HT}_{3}$ may well-correspond to the pentameric heterodimer assembled between all subunits and their splice variants, and also with other members of the cys-loop superfamily, like a4-nAChR nicotinic receptor $[46,107]$ although this association has not been detected in porcine native 5HT3 brain receptors [108]. On the contrary, association and coimmunoprecipitation of $5-\mathrm{HT}_{3}$ and $\mathrm{P} 2 \mathrm{X}_{2}$ ATP-gated channels has been reported [109].

All subunits have been found mainly in human intestine [110]. 5- $\mathrm{HT}_{3}$ mRNA was found in rat hippocampus primarily on interneurons, mediating indirect inhibitory effects on pyramidal neuron populations [111]. On the contrary, 5$\mathrm{HT}_{3}$ was found in human hippocampus with predominant immunoreactivity associated with pyramidal neurons in $\mathrm{CA}_{2}$ and $\mathrm{CA}_{3}$; transcripts were also identified so hippocampal cells can produce $5-\mathrm{HT}_{3 \mathrm{~A}}$ and $5-\mathrm{HT}_{3 \mathrm{~B}}$ functionally isoforms of this ion channel [112].

8.12. 5-HT $\mathrm{T}_{4}$ Receptors. The 5- $\mathrm{HT}_{4}$ receptor was first described in the central nervous system [113] stimulating adenylate cyclase; with some useful radioligands, it was showed to be distributed in hippocampus. It was cloned [114] and mRNA was localized in hippocampus by in situ hybridization [115].
The $5-\mathrm{HT}_{4}$ receptor gene is very complex and has several possible splice variants; there are at least nine receptor splice variants reported with a number of carboxyterminal variants but no difference in affinity for agonists or antagonists [41]. There is evidence that suggests that $5-\mathrm{HT}_{4}$ receptor activity enhances cognition and provides neuroprotection, particularly on hippocampal effects [116]; $5-\mathrm{HT}_{4}$ receptors on hippocampal cholinergic axon terminals are neurotransmitter release facilitating [70].

8.13. $5-\mathrm{HT}_{5}$ Receptors. The $5-\mathrm{HT}_{5}$ receptor group consists of two members: $5-\mathrm{HT}_{5 \mathrm{~A}}$ and $5-\mathrm{HT}_{5 \mathrm{~B}}$; human $5-\mathrm{HT}_{5 \mathrm{~B}}$ has been described, but it fails to encode a functional protein due to the presence of stop codons in the sequence [117-119]. They still lack physiological correlation, in part for the lack of selective agonists; the transductions pathways have not been well established although negatively coupling to adenylate cyclase has been reported $[41,43,120]$.

8.14. $5-H T_{5 A}$. Cloning and distribution of $5-\mathrm{HT}_{5 \mathrm{~A}}$ receptor has been reported, finding high concentration in hippocampus [119, 121, 122]. Although this receptor is a well-recognized GPCR protein, the negatively coupling to adenylated cyclase is not well established [120, 123-125], and furthermore, its coupling to multiple signal transduction pathways has been reported [126]. The $5-\mathrm{HT}_{5 \mathrm{~A}}$ receptor is expressed predominantly by astrocytes with very weak neuronal immunoreactivity [120].

8.15. 5- $-\mathrm{HT}_{5 \mathrm{~B}}$. Cloning and distribution of $5-\mathrm{HT}_{5 \mathrm{~B}}$ receptor has been reported as well, finding this receptor in hippocampus $[119,127]$. The levels of expression of $5-\mathrm{HT}_{5 \mathrm{~B}} \mathrm{mRNA}$ in hippocampus were high, with predominant expression in CA1 pyramidal cells [128]. It is a pseudogene in man [129], and it has been proposed that the upregulation found (particularly in hippocampus) for mice $5-\mathrm{HT}_{5 \mathrm{~B}}$ receptor, in response of social isolation stress, might be undertaken in humans by another receptor like $5-\mathrm{HT}_{5 \mathrm{~A}}[130]$.

8.16. 5-HT $\mathrm{T}_{6}$ Receptors. Ruat et al. (1993) cloned 5- $\mathrm{HT}_{6}$ receptor [131], starting from the sequence of rat histamine $\mathrm{H} 2$ receptor with two transcripts evidenced. mRNA was detected in hippocampus and in transfected COS-7 cells 5$\mathrm{HT}_{6}$ receptor was positively coupled to adenylate cyclase. Hybridization signal of $5-\mathrm{HT}_{6}$ mRNA was detected in CA1, CA2, and CA3 fields of hippocampus as well as in dentate gyrus [128].

8.17. 5-HT 7 Receptors. Ruat et al. (1993) also cloned the putative $5-\mathrm{HT}_{7}$ receptor and localized it at hippocampus [132]. It is differentially expressed in CA1 cells preferentially localized on the cell body but absent in interneurons [133]. The expression in the limbic areas suggests that these receptors mediate serotoninergic controls in functions like mood, learning, or neuroendocrine and vegetative behaviors. The emerging functions of hippocampus involve several neurotransmitter networks, where $5-\mathrm{HT}_{7}$ receptors can be functioning. AMPA receptor-mediated transmission between CA3 and CA1 pyramidal neurons is enhanced 
postsynaptically by $5-\mathrm{HT}_{7}$, while $5-\mathrm{HT}_{1 \mathrm{~A}}$ receptors inhibit this transmission both pre- and postsynaptically [134].

\section{Serotonergic Modulation in Hippocampus}

Among the various major neurotransmitter signaling, like monoaminergic, glutamatergic, and nitrergic neurotransmitter systems that might be involved in some plastic modifications of hippocampus particularly after stress exposure [135], serotonergic system is very interesting for its complexity and regulation.

Almost all pre- and postsynaptic serotonin receptors have been identified in hippocampus; furthermore, the 5-HT transporter (SERT, 5-HTT) plays a key role in serotonergic neurotransmission, and it is condition-regulated in hippocampus $[136,137]$. In addition, tryptophan hydroxylase (TPH), the rate-limiting enzyme for producing serotonin, plays another key role in the regulation of this system; TPH1 and TPH2 have been found in hippocampus [138]. The other key enzyme in serotonergic system is monoamine oxidase A, responsible for 5-HT degradation [139], expressed in hippocampus as well.

Regulation of serotonin system is very important and disturbances in this matter are related to anatomical, functional and behavioural anomalies, including neurologic and psychiatric disorders as obsessive-compulsive disorder, bulimia, chronic impulsivity, obesity and drug addiction, aggression, -major- depression, suicide, anxiety, schizophrenia, mania, autism, Alzheimer's disease and also sudden infant death syndrome [43, 139-142].

The function of serotonin as neurotransmitter seems to be developed at last in evolution, and ionotropic channels are related to rapid neuronal activation, particularly in enteric nervous system [4]. Serotonin, as metabotropic effector, has been recognized as a trophic factor, particularly during development including morphogenetic activities as cell proliferation, migration and differentiation [137, 143]; during adulthood, depletion in serotonin decreases neurogenesis in the dentate gyrus [144] though 5-HT plays a critical role in the neuronal organization of the hippocampus [145].

Several metabotropic effects of serotonin have been related to brain-derived neurotrophic factor (BDNF) expression [144] and BDNF itself promotes the development and function of serotonergic neurons [140]. This kind of interaction between neurotrophic factors and neurotransmitters has been reported also with steroids; the regulation of HPA axis by serotonin and vice versa is well documented [146, 147]; sexual steroids have this intricate correlation as well [148]. The key for understanding these relationships is the existence of multiple receptors and ligand interaction for molecular signaling.

On the other hand, hippocampus-dependent memory formation uses long-term potentiation (LTP) as a pivotal role. Cross-talk between the cAMP signal transduction system and LTP has been reported, with a critical linkage between $\mathrm{Ca}^{2+}$ and cAMP signaling [149]. At this level, all of the serotonin receptors seem to be directly involved in the normal function of hippocampus in mood regulation and memory formation; neurogenesis is thought to be one of the involved processes for long lasting changes related to hippocampal function, particularly because dentate gyrus is one of the prominent areas of adult brain neurogenesis [150].

The $5-\mathrm{HT}_{1 \mathrm{~A}}$ is the most likely involved receptor in regulation of neurogenesis in the dentate gyrus [150]; it is expressed on raphe serotonin neurons as an autoreceptor [151], acting as a negative regulator of neuronal activity in presynaptic locations in hippocampus, with very important function in the balance of serotonin reservoirs. $5-\mathrm{HT}_{1 \mathrm{~A}}$ also inhibits neuronal firing, activating G-protein-gated inwardly rectifying potassium (GIRK) currents and inhibiting $\mathrm{Ca}^{2+}$ channels [44]; it is involved in the inhibition of long-term potentiation (LTP) by the inhibition of NMDA function [152].

As one of the most "important" members of serotonin receptors, $5-\mathrm{HT}_{1 \mathrm{~A}}$ receptor is the best characterized and its ligands are used extensively. The mutant (knockout) mice lacking this receptor exhibits enhanced anxiety-related behaviour $[153,154]$. The "specific" $5-\mathrm{HT}_{1 \mathrm{~A}}$ ligand $8-\mathrm{OH}-$ DPAT has been used to establish the roles of this receptor as trophic factor and in neurotransmission as well, but 5HTT (SERT) recognizes this ligand and likewise modulates anxiety-related behaviour $[136,155]$.

The therapeutic effects of serotonin-selective reuptake inhibitors (SSRI), "specifically" acting on SERT function, are well documented, and several theories are proposed to explain the retarded actions in successfully treated patients [156-158]. SSRIs are the most widely prescribed class of antidepressants, which increases synaptic levels of 5HT in hours or days, but exerts the therapeutic response several weeks later [159]. The increasing levels of 5-HT cause a desensitization of $5-\mathrm{HT}_{1 \mathrm{~A}}$ autoreceptors with a lesser inhibition caused by this receptor in raphe neurons, leading to a facilitation of 5-HT signaling [160]. There is a differential response of SSRI's desensitizing $5-\mathrm{HT}_{1 \mathrm{~A}}$ presynaptic or postsynaptic receptors; the specific serotonin receptor antagonist WAY 100635 also promotes differential changes in autoreceptors compared to postsynaptic $5-\mathrm{HT}_{1 \mathrm{~A}}$ receptors $[160,161]$.

SERT and $5-\mathrm{HT}_{1 \mathrm{~A}}$ are the most studied therapeutic targets although several serotonin receptors are involved in hippocampus activities, particularly $5-\mathrm{HT}_{4}, 5-\mathrm{HT}_{6}$, and $5-\mathrm{HT}_{7}$ that activate cAMP signaling increasing CREB, which may increase the expression of BDNF [150]. Furthermore, 5- $\mathrm{HT}_{4}$ activation may cause a faster direct activation of 5-HT neurons, increasing their firing and causing desensitization of 5$\mathrm{HT}_{1 \mathrm{~A}}$ [159]. 5- $\mathrm{HT}_{2}$ receptors involve an alternative signaling pathway to cAMP, where increasing $\mathrm{Ca}^{2+}$ levels is of particular importance, relying on the crosstalk between cAMP signaling and $\mathrm{Ca}^{2+}$-regulated adenylyl cyclases. Knockout phenotype for $5-\mathrm{HT}_{2 \mathrm{~A}}$ shows decreased, anxiety while the one for $5-\mathrm{HT}_{2 \mathrm{C}}$ shows increased appetite, overweight, and cognitive impairment. Serotonin receptor $5-\mathrm{HT}_{2} \mathrm{C}$ is probably the most important receptor related to food intake and energy balance (satiety and obesity), with viable targeting for weight control [20].

The most representative neurotransmitter receptor for serotonin in rapid actions is the ionotropic $5-\mathrm{HT}_{3}$, which 


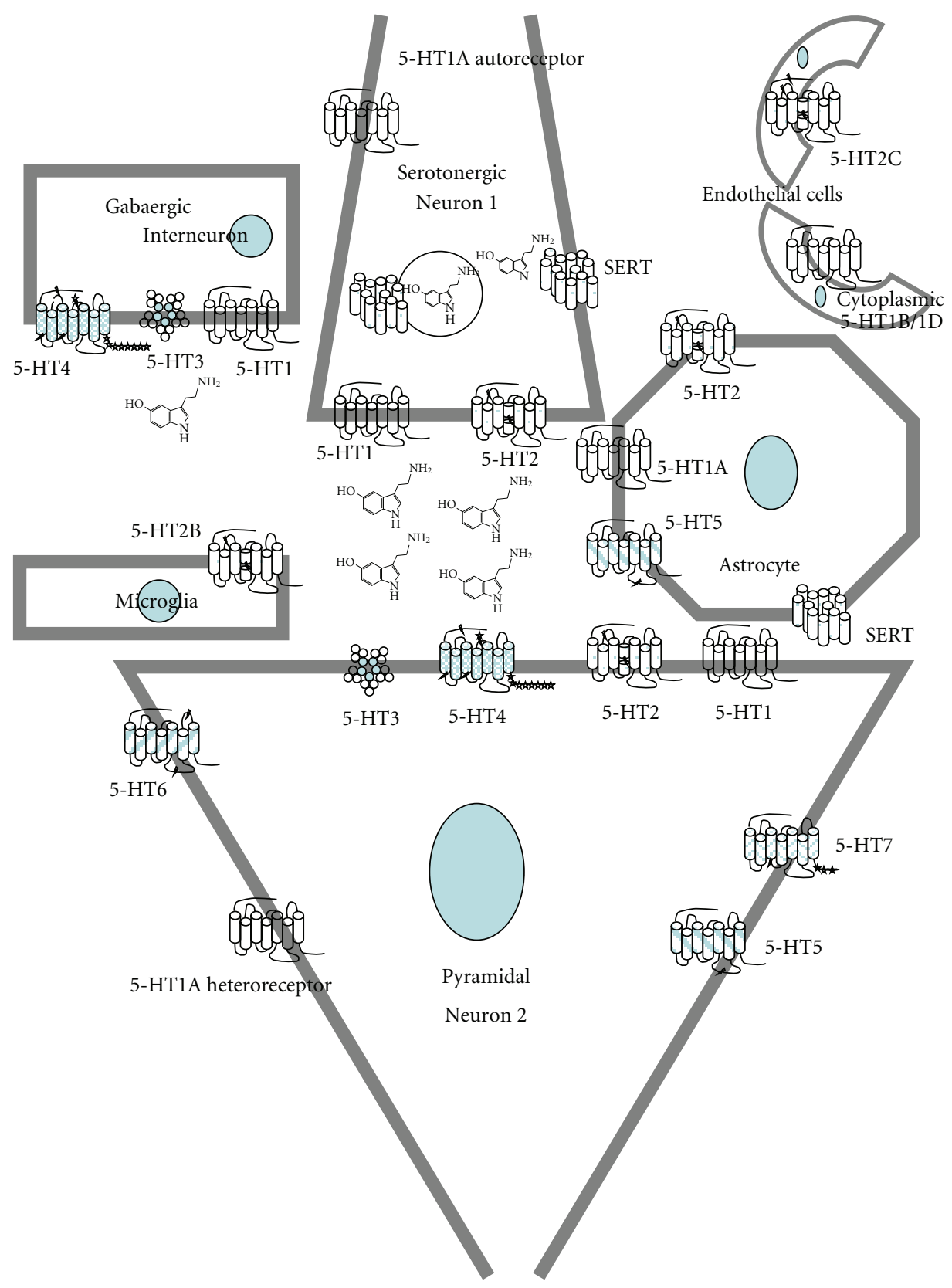

FIGURE 6: Serotonin receptors in hippocampus. The functional glia-neuron-vascular cells network uses several serotonin receptors (5-HTRs). The 7TMD images of each subtype receptor are represented with the defined number of exons that code for the mature protein (Bockaert et al., 2006) [44]; putative intron location in correspondent pre-mRNA is marked by a lightning symbol ( $\{$ ); alternative splicing sites are marked with stars $(\star \star \star)$. Neuron metabotropic 5-HTRs are mainly somatodendritic volume receptors although there is an association with synaptic specializations for some of them. $5-\mathrm{HT}_{3}$ with the five 4TMD subunits of a ligand activated ion channel is shown as synaptic receptor although this fact remains to be determined in hippocampus. Microglia is also included in the network for its relevance in pathophysiological responses, with 5- $\mathrm{HT}_{2 B}$ receptor expression (Capone et al., 2007) [90]. The 12TMD image of the serotonin transporter (SERT; 5-HTT) and vesicular monoamine transporter (VMAT) are represented in the serotonergic neuron and only SERT in the astrocyte.

is also involved in LTP modulation in hippocampus [162]. The knockout phenotype for $5-\mathrm{HT}_{3 \mathrm{~A}}$ has reduced pain perception and variants of the $5-\mathrm{HT}_{3 \mathrm{~A}}$ receptor have been associated with bipolar disorder and schizophrenia [43].

Serotonergic neuronal-glial interactions (Figure 6) have been proposed to play a significant role in the development of several CNS pathologies [163]. Some serotonin receptors are mainly expressed in glia. $5-\mathrm{HT}_{5 \mathrm{~A}}$ correlates with astrocyte maturity and activity, increasing its levels after induced gliosis [120] although its expression in pyramidal cells of hippocampus has been reported [117]. Addition of cAMP analogues to astrocyte cultures decreases $5-\mathrm{HT}_{1 \mathrm{~A}}$ expression and increases $5-\mathrm{HT}_{5 \mathrm{~A}}$, therefore suggesting a direct neuronal regulation of astrocyte homeostasis, as cAMP intracellular 
increases might activate and sensitize astrocytes to respond at serotonin signaling from neurons that can supress gliosis in vivo [120].

Each cell type can modify its serotonin receptor expression depending on the differentiation time and relationship in a particular network. Mouillet-Richard et al. (2000) have shown the differentiating changes than inducted serotonergic $1 \mathrm{C} 11^{* 5 \mathrm{HT}}$ cells can exhibit [164], sequentially expressing three different serotonin receptor subtypes $\left(5-\mathrm{HT}_{1 \mathrm{~B} / 1 \mathrm{D}}, 5-\right.$ $\mathrm{HT}_{2 \mathrm{~B}}$, and $\left.5-\mathrm{HT}_{2 \mathrm{~A}}\right)$. Although cell cultures do not represent reliable conditions of in vivo differentiation, they help us understand how cells can adapt to changing media. The 5$\mathrm{HT}_{2}$ receptors are referred to as programmable receptors that may not influence development although this process affect their number, affinity, or function; the coupling efficiency of the receptor may change in time, in correlation to a developmental change of phosphatidylinositol hydrolysissecond messenger system [165].

In conclusion, the specific changes that modulate serotonin signaling can be performed by serotonin itself; the levels of serotonin that can be reached in the synapses, or as a volume transmission, is of outstanding importance to understand the rate of change in the 5-HT signaling itself, time of action might conduce to one response or the contrary, considering that all the cell types in hippocampus are involved in this modulation and function. Serotonin can act directly into neuron and glia after SERT incorporation, an ancient function for this biogenic amine and probably with more importance during development.

\section{Conflict of Interests}

The authors do not have conflict of interests. Support for publication is received from Universidad Autónoma de Querétaro.

\section{Acknowledgments}

The authors appreciate the suggestions of Jesica Escobar in the preparation of this paper. They would also like to acknowledge Salvador and Diego Lecona for editing the English content of this paper.

\section{References}

[1] M. M. Rapport, A. A. Green, and I. H. Page, "Serum vasoconstrictor (serotonin). IV. Isolation and characterization," The Journal of Biological Chemistry, vol. 176, pp. 1243-1251, 1948.

[2] M. Berger, J. A. Gray, and B. L. Roth, "The expanded biology of serotonin," Annual Review of Medicine, vol. 60, pp. 355366, 2009.

[3] V. Erspamer and B. Asero, "Identification of enteramine, the specific hormone of the enterochromaffin cell system, as 5hydroxytryptamine," Nature, vol. 169, no. 4306, pp. 800-801, 1952.

[4] K. Turlejski, "Evolutionary ancient roles of serotonin: longlasting regulation of activity and development," Acta Neurobiologiae Experimentalis, vol. 56, no. 2, pp. 619-636, 1996.
[5] D. E. Nichols and C. D. Nichols, "Serotonin receptors," Chemical Reviews, vol. 108, no. 5, pp. 1614-1641, 2008.

[6] S. Park, K. Kang, S. W. Lee, M. J. Ahn, J. M. Bae, and K. Back, "Production of serotonin by dual expression of tryptophan decarboxylase and tryptamine 5-hydroxylase in Escherichia coli," Applied Microbiology and Biotechnology, vol. 89, no. 5, pp. 1387-1394, 2011.

[7] G. Rudnick, "What is an antidepressant binding site doing in a bacterial transporter," ACS Chemical Biology, vol. 2, no. 9, pp. 606-609, 2007.

[8] C. Yanofsky, "RNA-based regulation of genes of tryptophan synthesis and degradation, in bacteria," RNA, vol. 13, no. 8 , pp. 1141-1154, 2007.

[9] A. Lazcano, "Historical development of origins research," Cold Spring Harbor Perspectives in Biology, vol. 2, no. 11, Article ID a002089, 2010.

[10] D. L. Murphy, M. A. Fox, K. R. Timpano et al., "How the serotonin story is being rewritten by new gene-based discoveries principally related to SLC6A4, the serotonin transporter gene, which functions to influence all cellular serotonin systems," Neuropharmacology, vol. 55, no. 6, pp. 932-960, 2008.

[11] G. A. Buznikov, H. W. Lambert, and J. M. Lauder, "Serotonin and serotonin-like substances as regulators of early embryogenesis and morphogenesis," Cell and Tissue Research, vol. 305, no. 2, pp. 177-186, 2001.

[12] E. J. Essman, "The serotonergic system in Tetrahymena pyriformis," La Ricerca in Clinica e in Laboratorio, vol. 17, no. 1, pp. 77-82, 1987.

[13] G. Csaba, "Presence in and effects of pineal indoleamines at very low level of phylogeny," Experientia, vol. 49, no. 8, pp. 627-634, 1993.

[14] N. Paulmann, M. Grohmann, J. P. Voigt et al., "Intracellular serotonin modulates insulin secretion from pancreatic $\beta$ cells by protein serotonylation," PLoS Biology, vol. 7, no. 10, Article ID e1000229, 2009.

[15] C. P. Mercado, E. Ziu, and F. Kilic, "Communication between 5-HT and small GTPases," Current Opinion in Pharmacology, vol. 11, no. 1, pp. 23-28, 2011.

[16] N. M. Barnes, "5-HT: the promiscuous and happy hormone! editorial overview," Current Opinion in Pharmacology, vol. 11, no. 1, pp. 1-2, 2011.

[17] Y. Charnay and L. Léger, "Brain serotonergic circuitries," Dialogues in Clinical Neuroscience, vol. 12, no. 4, pp. 471-487, 2010.

[18] K. Yao, J. Fang, Y. L. Yin, Z. M. Feng, Z. R. Tang, and G. Wu, "Tryptophan metabolism in animals: important roles in nutrition and health," Frontiers in Bioscience, vol. 3, pp. 286297, 2011.

[19] D. J. Hayes and A. J. Greenshaw, "5-HT receptors and rewardrelated behaviour: a review," Neuroscience and Biobehavioral Reviews, vol. 35, no. 6, pp. 1419-1449, 2011.

[20] F. M. Feijó, M. C. Bertoluci, and C. Reis, "Serotonin and hypothalamic control of hunger: a review," Revista da Associação Médica Brasileira, vol. 57, no. 1, pp. 74-77, 2011.

[21] G. P. Ahern, " 5-HT and the immune system," Current Opinion in Pharmacology, vol. 11, no. 1, pp. 29-33, 2011.

[22] A. Dahlström and K. Fuxe, "Localization of monoamines in the lower brain stem," Experientia, vol. 20, no. 7, pp. 398-399, 1964.

[23] H. W. Steinbusch, "Distribution of serotonin-immunoreactivity in the central nervous system of the rat-cell bodies and terminals," Neuroscience, vol. 6, no. 4, pp. 557-618, 1981. 
[24] W. Wisden, "Cre-ating ways to serotonin," Frontiers in Neuroscience, vol. 4, p. 167, 2010.

[25] B. M. Twarog and I. H. Page, "Serotonin content of some mammalian tissues and urine and a method for its determination," The American Journal of Physiology, vol. 175, no. 1, pp. 157-161, 1953.

[26] J. G. Hensler, "Serotonergic modulation of the limbic system," Neuroscience and Biobehavioral Reviews, vol. 30, no. 2, pp. 203-214, 2006.

[27] M. E. Molliver, "Serotonergic neuronal systems: what their anatomic organization tells us about function," Journal of Clinical Psychopharmacology, vol. 7, supplement 6, pp. 3S23S, 1987.

[28] T. F. Freund, A. I. Gulyás, L. Acsády, T. Görcs, and K. Tóth, "Serotonergic control of the hippocampus via local inhibitory interneurons," Proceedings of the National Academy of Sciences of the United States of America, vol. 87, no. 21, pp. 8501-8505, 1990.

[29] M. Bijak, "Monoamine modulation of the synaptic inhibition in the hippocampus," Acta Neurobiologiae Experimentalis, vol. 56, no. 1, pp. 385-395, 1996.

[30] L. A. Mamounas, C. A. Mullen, E. O’Hearn, and M. E. Molliver, "Dual serotoninergic projections to forebrain in the rat: morphologically distinct 5-HT axon terminals exhibit differential vulnerability to neurotoxic amphetamine derivatives," Journal of Comparative Neurology, vol. 314, no. 3, pp. 558-586, 1991.

[31] R. P. Vertes, "A PHA-L analysis of ascending projections of the dorsal raphe nucleus in the rat," Journal of Comparative Neurology, vol. 313, no. 4, pp. 643-668, 1991.

[32] G. García-Alcocer, G. Sarabia-Altamirano, A. MartínezTorres, and R. Miledi, "Developmental expression of 5-HT5A receptor mRNA in the rat brain," Neuroscience Letters, vol. 379, no. 2, pp. 101-105, 2005.

[33] G. García-Alcocer, L. C. B. Segura, M. G. Peña, A. MartínezTorres, and R. Miledi, "Ontogenetic distribution of 5-HT2C, 5-HT5A, and 5-HT7 receptors in the rat hippocampus," Gene Expression, vol. 13, no. 1, pp. 53-57, 2005.

[34] J. H. Gaddum and Z. P. Picarelli, "Two kinds of tryptamine receptor," British Journal of Pharmacology and Chemotherapy, vol. 12, no. 3, pp. 323-328, 1957.

[35] J. L. Bennett and G. K. Aghajanian, "D LSD binding to brain homogenates: possible relationship to serotonin receptors," Life Sciences, vol. 15, no. 11, pp. 1935-1944, 1974.

[36] G. Fillion, M. P. Fillion, J. Jacob, and J. C. Rousselle, "5 HT and LSD high affinity binding sites to brain synaptosomal membranes," British Journal of Pharmacology, vol. 58, no. 3, pp. 425P-426P, 1976.

[37] S. J. Peroutka and S. H. Snyder, "Multiple serotonin receptors: differential binding of $[3 \mathrm{H}] 5$-hydroxytryptamine, $[3 \mathrm{H}] \mathrm{ly}$ sergic acid diethylamide and [3H] spiroperidol," Molecular Pharmacology, vol. 16, no. 3, pp. 687-699, 1979.

[38] P. B. Bradley, G. Engel, and W. Feniuk, "Proposals for the classification and nomenclature of functional receptors for 5hydroxytryptamine," Neuropharmacology, vol. 25, no. 6, pp. 563-576, 1986.

[39] D. Hoyer, D. E. Clarke, J. R. Fozard et al., "International union of pharmacology classification of receptors for 5-hydroxytryptamine (serotonin)," Pharmacological Reviews, vol. 46, no. 2, pp. 157-203, 1994.

[40] D. Hoyer, J. P. Hannon, and G. R. Martin, "Molecular, pharmacological adn functional diversity of 5-HT receptors," Pharmacology Biochemistry and Behavior, vol. 71, no. 4, pp. 533-554, 2002.
[41] J. Hannon and D. Hoyer, "Molecular biology of 5-HT receptors," Behavioural Brain Research, vol. 195, no. 1, pp. 198213, 2008.

[42] G. L. Collingridge, R. W. Olsen, J. Peters, and M. Spedding, "A nomenclature for ligand-gated ion channels," Neuropharmacology, vol. 56, no. 1, pp. 2-5, 2009.

[43] M. Filip and M. Bader, "Overview on 5-HT receptors and their role in physiology and pathology of the central nervous system," Pharmacological Reports, vol. 61, no. 5, pp. 761-777, 2009.

[44] J. Bockaert, S. Claeysen, C. Bécamel, A. Dumuis, and P. Marin, "Neuronal 5-HT metabotropic receptors: fine-tuning of their structure, signaling, and roles in synaptic modulation," Cell and Tissue Research, vol. 326, no. 2, pp. 553-572, 2006.

[45] N. M. Barnes, T. G. Hales, S. C. R. Lummis, and J. A. Peters, "The 5-HT3 receptor-the relationship between structure and function," Neuropharmacology, vol. 56, no. 1, pp. 273-284, 2009.

[46] J. A. van Hooft, A. D. Spier, J. L. Yakel, S. C. R. Lummis, and H. P. M. Vijverberg, "Promiscuous coassembly of serotonin $5-\mathrm{HT}_{3}$ and nicotinic $\alpha 4$ receptor subunits into $\mathrm{Ca}^{2+}$-permeable ion channels," Proceedings of the National Academy of Sciences of the United States of America, vol. 95, no. 19, pp. 11456-11461, 1998.

[47] R. Fredriksson, M. C. Lagerström, L. G. Lundin, and H. B. Schiöth, "The G-protein-coupled receptors in the human genome form five main families. Phylogenetic analysis, paralogon groups, and fingerprints," Molecular Pharmacology, vol. 63, no. 6, pp. 1256-1272, 2003.

[48] T. Kumari, B. Pant, and K.R. Pardasani, "A model for the evaluation of domain based classification of GPCR," Bioinformation, vol. 4, no. 4, pp. 138-142, 2009.

[49] J. Bockaert and J. P. Pin, "Molecular tinkering of G proteincoupled receptors: an evolutionary success," EMBO Journal, vol. 18, no. 7, pp. 1723-1729, 1999.

[50] T. D. Werry, K. J. Gregory, P. M. Sexton, and A. Christopoulos, "Characterization of serotonin 5-HT2C receptor signaling to extracellular signal-regulated kinases 1 and 2," Journal of Neurochemistry, vol. 93, no. 6, pp. 1603-1615, 2005.

[51] N. Wettschureck and S. Offermanns, "Mammalian G proteins and their cell type specific functions," Physiological Reviews, vol. 85, no. 4, pp. 1159-1204, 2005.

[52] K. DeFea, " $\beta$-arrestins and heterotrimeric G-proteins: collaborators and competitors in signal transduction," British Journal of Pharmacology, vol. 153, supplement 1, pp. S298S309, 2008.

[53] K. A. DeFea, " $\beta$-arrestins as regulators of signal termination and transduction: how do they determine what to scaffold?" Cellular Signalling, vol. 23, no. 4, pp. 621-629, 2010.

[54] B. L. Roth, "Irving Page lecture 5-HT(2A) serotonin receptor biology: interacting proteins, kinases and paradoxical regulation," Neuropharmacology, vol. 61, no. 3, pp. 348-354, 2011.

[55] M. A. Davies, C. Y. Chang, and B. L. Roth, "Polymorphic and posttranscriptional modifications of 5-HT receptor structure. functional and pathological implications," in The Serotonin Receptors, B. L. Roth, Ed., pp. 59-90, Humana Press, New Jersy, NJ, USA, 2006. 
[56] E. C. Azmitia and W. F. Marovitz, "In vitro hippocampal uptake of tritiated serotonin $\left({ }^{3} \mathrm{H}-5 \mathrm{HT}\right)$ : a morphological, biochemical, and pharmacological approach to specificity," Journal of Histochemistry and Cytochemistry, vol. 28, no. 7, pp. 636-644, 1980.

[57] A. Fargin, J. R. Raymond, M. J. Lohse, B. K. Kobilka, M. G. Caron, and R. J. Lefkowitz, "The genomic clone G-21 which resembles a $\beta$-adrenergic receptor sequence encodes the 5HT1A receptor," Nature, vol. 335, no. 6188, pp. 358-360, 1988.

[58] H. Gozlan, S. El Mestikawy, and L. Pichat, "Identification of presynaptic serotonin autoreceptors using a new ligand: $3 \mathrm{H}-$ PAT," Nature, vol. 305, no. 5930, pp. 140-142, 1983.

[59] D. Hoyer, A. Pazos, A. Probst, and J. M. Palacios, "Serotonin receptors in the human brain. I. Characterization and autoradiographic localization of 5-HT(1A) recognition sites. Apparent absence of 5-HT(1B) recognition sites," Brain Research, vol. 376, no. 1, pp. 85-96, 1986.

[60] D. Vergé, G. Daval, M. Marcinkiewicz et al., "Quantitative autoradiography of multiple 5-HT1 receptor subtypes in the brain of control or 5,7-dihidroxytryptamine-treated rats," Journal of Neuroscience, vol. 6, no. 12, pp. 3474-3478, 1986.

[61] S. El Mestikawy, D. Taussig, H. Gozlan, M. B. Emerit, M. Ponchant, and M. Hamon, "Chromatographic analyses of the serotonin 5-HTA receptor solubilized from the rat hippocampus," Journal of Neurochemistry, vol. 53, no. 5, pp. 1555-1566, 1989.

[62] Y. Chaput, P. Blier, and C. de Montigny, "In vivo electrophysiological evidence for the regulatory role of autoreceptors on serotonergic terminals," Journal of Neuroscience, vol. 6, no. 10, pp. 2796-2801, 1986.

[63] S. Muchimapura, R. Mason, and C. A. Marsden, "Effect of isolation rearing on pre- and post-synaptic serotonergic function in the rat dorsal hippocampus," Synapse, vol. 47, no. 3, pp. 209-217, 2003.

[64] E. C. Azmitia, P. J. Gannon, N. M. Kheck, and P. M. WhitakerAzmitia, "Cellular localization of the 5-HT(1A) receptor in primate brain neurons and glial cells," Neuropsychopharmacology, vol. 14, no. 1, pp. 35-46, 1996.

[65] M. M. Voigt, D. J. Laurie, P. H. Seeburg, and A. Bach, "Molecular cloning and characterization of a rat brain cDNA encoding a 5-hydroxytryptamine $1 \mathrm{~B}$ receptor," EMBO Journal, vol. 10, no. 13, pp. 4017-4023, 1991.

[66] D. Hoyer, G. Engel, and H. O. Kalkman, "Characterization of the $5-\mathrm{HT}_{1 \mathrm{~B}}$ recognition site in rat brain: binding studies with $\left[{ }^{125} \mathrm{I}\right]$ iodocyanopindolol," European Journal of Pharmacology, vol. 118, no. 1-2, pp. 1-12, 1985.

[67] M. Egeland, J. Warner-Schmidt, P. Greengard, and P. Svenningsson, "Co-expression of serotonin 5-HT(1B) and 5$\mathrm{HT}(4)$ receptors in p11 contaning cells in cerebral cortex, hippocampus, caudate-putamen and cerebellum," Neuropharmacology, vol. 61, no. 3, pp. 442-450, 2011.

[68] B. Mlinar, C. Falsini, and R. Corradetti, "Pharmacological characterization of 5-HT1B receptor-mediated inhibition of local excitatory synaptic transmission in the CA1 region of rat hippocampus," British Journal of Pharmacology, vol. 138, no. 1, pp. 71-80, 2003.

[69] J. D. Guo and D. G. Rainnie, "Presynaptic 5-HT1B receptormediated serotonergic inhibition of glutamate transmission in the bed nucleus of the stria terminalis," Neuroscience, vol. 165, no. 4, pp. 1390-1401, 2010.

[70] K. B. Fink and M. Göthert, "5-HT receptor regulation of neurotransmitter release," Pharmacological Reviews, vol. 59, no. 4, pp. 360-417, 2007.
[71] M. W. Hamblin and M. A. Metcalf, "Primary structure and functional characterization of a human 5-HT(1D)-type serotonin receptor," Molecular Pharmacology, vol. 40, no. 2, pp. 143-148, 1991.

[72] R. L. Weinshank, J. M. Zgombick, M. J. Macchi, T. A. Branchek, and P. R. Harting, "Human serotonin 1D receptor is encoded by a subfamily of two distinct genes: 5-HT1D $\alpha$ and 5-HT1D $\beta$," Proceedings of the National Academy of Sciences of the United States of America, vol. 89, no. 8, pp. 8630-8634, 1992.

[73] A. T. Bruinvels, J. M. Palacios, and D. Hoyer, "Autoradiographic characterisation and localisation of 5-HT1D compared to 5-HT1B binding sites in rat brain," NaunynSchmiedeberg's Archives of Pharmacology, vol. 347, no. 6, pp. 569-582, 1993.

[74] G. McAllister, A. Charlesworth, C. Snodin et al., "Molecular cloning of a serotonin receptor from human brain (5HT1E): a fifth 5HT1-like subtype," Proceedings of the National Academy of Sciences of the United States of America, vol. 89, no. 12, pp. 5517-5521, 1992.

[75] S. Leonhardt, K. Herrick-Davis, and M. Titeler, "Detection of a novel serotonin receptor subtype (5-HT1E) in human brain: interaction with a GTP-binding protein," Journal of Neurochemistry, vol. 53, no. 2, pp. 465-471, 1989.

[76] N. Amlaiky, S. Ramboz, U. Boschert, J. L. Plassat, and R. Hen, "Isolation of a mouse "5HT1E-like" serotonin receptor expressed predominantly in hippocampus," Journal of Biological Chemistry, vol. 267, no. 28, pp. 19761-19764, 1992.

[77] N. Adham, H. T. Kao, L. E. Schechter et al., "Cloning of another human serotonin receptor (5-HT1F): a fifth 5HT1 receptor subtype coupled to the inhibition of adenylate cyclase," Proceedings of the National Academy of Sciences of the United States of America, vol. 90, no. 2, pp. 408-412, 1993.

[78] A. Pazos, R. Cortés, and J. M. Palacios, "Quantitative autoradiographic mapping of serotonin receptors in the rat brain. II. Serotonin-2 receptors," Brain Research, vol. 346, no. 2, pp. 231-249, 1985.

[79] C. Ullmer, H. G. Boddeke, K. Schmuck, and H. Lübbert, “5HT2B receptor-mediated calcium release from ryanodinesensitive intracellular stores in human pulmonary artery endothelial cells," British Journal of Pharmacology, vol. 117, no. 6, pp. 1081-1088, 1996.

[80] D. Hoyer, A. Pazos, A. Probst, and J. M. Palacios, "Serotonin receptors in the human brain. II. Characterization and autoradiographic localization of 5-HT1C and 5-HT2 recognition sites," Brain Research, vol. 376, no. 1, pp. 97-107, 1986.

[81] D. B. Pritchett, A. W. Bach, M. Wozny et al., "Structure and functional expression of cloned rat serotonin 5HT-2 receptor," EMBO Journal, vol. 7, no. 13, pp. 4135-4140, 1988.

[82] D. Julius, K. N. Huang, T. J. Livelli, R. Axel, and T. M. Jessell, "The 5HT2 receptor defines a family of structurally distinct but functionally conserved serotonin receptors," Proceedings of the National Academy of Sciences of the United States of America, vol. 87, no. 3, pp. 928-932, 1990.

[83] P. W. Burnet, S. L. Eastwood, and P. J. Harrison, "Detection and quantitation of 5-HT1A and $5 \mathrm{HT}(2 \mathrm{~A})$ receptor mRNAs in human hippocampus using a revel-se transcriptasepolymerase chain reaction (RT-PCR) technique and their correlation with binding site densities and age," Neuroscience Letters, vol. 178, no. 1, pp. 85-89, 1994. 
[84] Q. H. Li, K. Nakadate, S. Tanaka-Nakadate, D. Nakatsuka, Y. Cui, and Y. Watanabe, "Unique expression patterns of 5HT2A and 5-HT2C receptors in the rat brain during postnatal development: western blot and immunohistochemical analyses," Journal of Comparative Neurology, vol. 469, no. 1, pp. 128-140, 2004.

[85] L. A. Miner, J. R. Backstrom, E. Sanders-Bush, and S. R. Sesack, "Ultrastructural localization of serotonin2A receptors in the middle layers of the rat prelimbic prefrontal cortex," Neuroscience, vol. 116, no. 1, pp. 107-117, 2003.

[86] T. Xu and S. C. Pandey, "Cellular localization of serotonin $(2 \mathrm{~A})(5 \mathrm{HT}(2 \mathrm{~A}))$ receptors in the rat brain," Brain Research Bulletin, vol. 51, no. 6, pp. 499-505, 2000.

[87] J. D. Kursar, D. L. Nelson, D. B. Wainscott, M. L. Cohen, and M. Baez, "Molecular cloning, functional expression, and pharmacological characterization of a novel serotonin receptor (5-hydroxytryptamine2F) from rat stomach fundus," Molecular Pharmacology, vol. 42, no. 4, pp. 549-557, 1992.

[88] D. W. Bonhaus, C. Bach, A. DeSouza et al., "The pharmacology and distribution of human 5-hydroxytryptamine2B (5HT2B) receptor gene products: comparison with 5- $\mathrm{HT}(2 \mathrm{~A})$ and 5-HT(2C) receptors," British Journal of Pharmacology, vol. 115 , no. 4, pp. 622-628, 1995.

[89] N. Sandén, T. Thorlin, F. Blomstrand, P. A. Persson, and E. Hansson, "5-Hydroxytryptamine2B receptors stimulate $\mathrm{Ca}^{2+}$ increases in cultured astrocytes from three different brain regions," Neurochemistry International, vol. 36, no. 4-5, pp. 427-434, 2000.

[90] C. Capone, C. Fabrizi, P. Piovesan et al., "2-Aminotetraline derivative protects from ischemia/reperfusion brain injury with a broad therapeutic window," Neuropsychopharmacology, vol. 32, no. 6, pp. 1302-1311, 2007.

[91] H. Lübbert, B. J. Hoffman, T. P. Snutch et al., "cDNA cloning of a serotonin 5-HT1C receptor by electrophysiological assays of mRNA-injected Xenopus oocytes," Proceedings of the National Academy of Sciences of the United States of America, vol. 84, no. 12, pp. 4332-4336, 1987.

[92] D. Julius, A. B. MacDermott, R. Axel, and T. M. Jessell, "Molecular characterization of a functional cDNA encoding the serotonin 1c receptor," Science, vol. 241, no. 4865, pp. 558-564, 1988.

[93] A. Pazos, D. Hoyer, and J. M. Palacios, "The binding of serotonergic ligands to the porcine choroid plexus: characterization of a new type of serotonin recognition site," European Journal of Pharmacology, vol. 106, no. 3, pp. 539-546, 1984.

[94] A. Pazos and J. M. Palacios, "Quantitative autoradiographic mapping of serotonin receptors in the rat brain. I. Serotonin1 receptors," Brain Research, vol. 346, no. 2, pp. 205-230, 1985.

[95] B. J. Hoffman and E. Mezey, "Distribution of serotonin 5 $\mathrm{HT}_{1 \mathrm{C}}$ receptor mRNA in adult rat brain," FEBS Letters, vol. 247, no. 2, pp. 453-462, 1989.

[96] S. M. Molineaux, T. M. Jessell, R. Axel, and D. Julius, “5 $\mathrm{HT}_{1 \mathrm{C}}$ receptor is a prominent serotonin receptor subtype in the central nervous system," Proceedings of the National Academy of Sciences of the United States of America, vol. 86, no. 17, pp. 6793-6797, 1989.

[97] G. Mengod, H. Nguyen, H. Le, C. Waeber, H. Lübbert, and J. M. Palacios, "The distribution and cellular localization of the serotonin $1 \mathrm{C}$ receptor mRNA in the rodent brain examined by in situ hybridization histochemistry. Comparison with receptor binding distribution," Neuroscience, vol. 35, no. 3, pp. 577-591, 1990.
[98] M. Pompeiano, J. M. Palacios, and G. Mengod, "Distribution of the serotonin 5-HT2 receptor family mRNAs: comparison between 5-HT2A and 5-HT2C receptors," Molecular Brain Research, vol. 23, no. 1-2, pp. 163-178, 1994.

[99] D. Abramowski, M. Rigo, D. Duc, D. Hoyer, and M. Staufenbiel, "Localization of the 5-hydroxytryptamine2C receptor protein in human and rat brain using specific antisera," Neuropharmacology, vol. 34, no. 12, pp. 1635-1645, 1995.

[100] D. A. Clemett, T. Punhani, M. S. Duxon, T. P. Blackburn, and K. C. Fone, "Immunohistochemical localisation of the 5HT2C receptor protein in the rat CNS," Neuropharmacology, vol. 39, no. 1, pp. 123-132, 2000.

[101] B. P. Richardson, G. Engel, P. Donatsch, and P. A. Stadler, "Identification of serotonin M-receptor subtypes and their specific blockade by a new class of drugs," Nature, vol. 316, no. 6024, pp. 126-131, 1985.

[102] A. V. Maricq, A. S. Peterson, A. J. Brake, R. M. Myers, and D. Julius, "Primary structure and functional expression of the 5HT3 receptor, a serotonin-gated ion channel," Science, vol. 254, no. 5030, pp. 432-437, 1991.

[103] P. A. Davies, M. Pistis, M. C. Hanna et al., "The SHT3B subunit is a major determinant of serotonin-receptor function," Nature, vol. 397, no. 6717, pp. 359-363, 1999.

[104] A. M. Karnovsky, L. F. Gotow, D. D. McKinley et al., "A cluster of novel serotonin receptor 3-like genes on human chromosome 3," Gene, vol. 319, no. 1-2, pp. 137-148, 2003.

[105] B. Niesler, B. Frank, J. Kapeller, and G. A. Rappold, “Cloning, physical mapping and expression analysis of the human 5-HT3 serotonin receptor-like genes HTR3C, HTR3D and HTR3E," Gene, vol. 310, no. 1-2, pp. 101-111, 2003.

[106] J. D. Holbrook, C. H. Gill, N. Zebda et al., "Characterization of 5-HT3C, 5-HT3D and 5-HT3E receptor subunits: evolution, distribution and function," Journal of Neurochemistry, vol. 108, no. 2, pp. 384-396, 2009.

[107] S. N. Sudweeks, J. A. Van Hooft, and J. L. Yakel, "Serotonin 5-HT3 receptor in rat CA1 hippocampal interneurons: functional and molecular characterization," Journal of Physiology, vol. 544, no. 3, pp. 715-726, 2002.

[108] S. Fletcher, J. M. Lindstrom, R. M. McKernan, and N. M. Barnes, "Evidence that porcine native 5-HT3 receptors do not contain nicotinic acetylcholine receptor subunits," Neuropharmacology, vol. 37, no. 3, pp. 397-399, 1998.

[109] É. Boué-Grabot, C. Barajas-López, Y. Chakfe et al., "Intracellular cross talk and physical interaction between two classes of neurotransmitter-gated channels," Journal of Neuroscience, vol. 23, no. 4, pp. 1246-1253, 2003.

[110] J. Kapeller, D. Möller, F. Lasitschka et al., "Serotonin receptor diversity in the human colon: expression of serotonin type 3 receptor subunits 5-HT3C, 5-HT3D, and 5-HT3E," Journal of Comparative Neurology, vol. 519, no. 3, pp. 420-432, 2011.

[111] L. H. Tecott, A. V. Maricq, and D. Julius, "Nervous system distribution of the serotonin 5-HT3 receptor mRNA," Proceedings of the National Academy of Sciences of the United States of America, vol. 90, no. 4, pp. 1430-1434, 1993.

[112] C. A. Brady, T. J. Dover, A. N. Massoura, A. P. Princivalle, A. G. Hope, and N. M. Barnes, "Identification of 5-HT3A and 5-HT3B receptor subunits in human hippocampus," Neuropharmacology, vol. 52, no. 5, pp. 1284-1290, 2007.

[113] A. Dumuis, R. Bouhelal, M. Sebben, and J. Bockaert, "A 5HT receptor in the central nervous system, positively coupled with adenylate cyclase, is antagonized by ICS 205 930," 
European Journal of Pharmacology, vol. 146, no. 1, pp. 187$188,1988$.

[114] C. Gerald, N. Adham, H. T. Kao et al., "The 5-HT4 receptor: molecular cloning and pharmacological characterization of two splice variants," EMBO Journal, vol. 14, no. 12, pp. 2806 2815, 1995.

[115] M. T. Vilaró, R. Cortés, C. Gerald, T. A. Branchek, J. M. Palacios, and G. Mengod, "Localization of 5-HT4 receptor mRNA in rat brain by in situ hybridization histochemistry," Molecular Brain Research, vol. 43, no. 1-2, pp. 356-360, 1996.

[116] E. G. Mohler, S. Shacham, S. Noiman et al., "VRX-03011, a novel 5-HT4 agonist, enhances memory and hippocampal acetylcholine efflux," Neuropharmacology, vol. 53, no. 4, pp. 563-573, 2007.

[117] J. L. Plassat, U. Boschert, N. Amlaiky, and R. Hen, "The mouse 5HT5 receptor reveals a remarkable heterogeneity within the 5HT1D receptor family," EMBO Journal, vol. 11, no. 13, pp. 4779-4786, 1992.

[118] M. G. Erlander, T. W. Lovenberg, B. M. Baron et al., "Two members of a distinct subfamily of 5-hydroxytryptamine receptors differentially expressed in rat brain," Proceedings of the National Academy of Sciences of the United States of America, vol. 90, no. 8, pp. 3452-3456, 1993.

[119] H. Matthes, U. Boschert, N. Amlaiky et al., "Mouse 5hydroxytryptamine $5 \mathrm{~A}$ and 5-hydroxytryptamine5B receptors define a new family of serotonin receptors: cloning, functional expression, and chromosomal localization," Molecular Pharmacology, vol. 43, no. 3, pp. 313-319, 1993.

[120] M. J. Carson, E. A. Thomas, P. E. Danielson, and J. G. Sutcliffe, "The 5-HT5A serotonin receptor is expressed predominantly by astrocytes in which it inhibits cAMP accumulation: a mechanism for neuronal suppression of reactive astrocytes," GLIA, vol. 17, no. 4, pp. 317-326, 1996.

[121] M. Pasqualetti, M. Ori, I. Nardi, M. Castagna, G. B. Cassano, and D. Marazziti, "Distribution of the 5-HT5A serotonin receptor mRNA in the human brain," Molecular Brain Research, vol. 56, no. 1-2, pp. 1-8, 1998.

[122] K. R. Oliver, A. M. Kinsey, A. Wainwright, and D. J. S. Sirinathsinghji, "Localization of $5-\mathrm{ht}_{5 \mathrm{~A}}$ receptor-like immunoreactivity in the rat brain," Brain Research, vol. 867, no. 1-2, pp. 131-142, 2000.

[123] B. J. Francken, M. Jurzak, J. F. Vanhauwe, W. H. Luyten, and J. E. Leysen, "The human $5-\mathrm{ht}_{5 \mathrm{~A}}$ receptor couples to $\mathrm{G}(\mathrm{i}) / \mathrm{G}(\mathrm{o})$ proteins and inhibits adenylate cyclase in HEK 293 cells," European Journal of Pharmacology, vol. 361, no. 2-3, pp. 299309, 1998.

[124] B. J. B. Francken, K. Josson, P. Lijnen, M. Jurzak, W. H. M. L. Luyten, and J. E. Leysen, "Human 5-hydroxytryptamine(5A) receptors activate coexpressed $\mathrm{G}(\mathrm{i})$ and $\mathrm{G}(\mathrm{o})$ proteins in Spodoptera frugiperda 9 cells," Molecular Pharmacology, vol. 57, no. 5, pp. 1034-1044, 2000.

[125] B. J. B. Francken, J. F. Vanhauwe, K. Josson, M. Jurzak, W. H. Luyten, and J. E. Leysen, "Reconstitution of human 5hydroxytryptamine $_{5 \mathrm{~A}}$ receptor-G protein coupling in $\mathrm{E}$. coli and Sf9 cell membranes with membranes from Sf9 cells expressing mammalian G proteins," Receptors and Channels, vol. 7, no. 4, pp. 303-318, 2001.

[126] M. Noda, S. Yasuda, N. Okada et al., "Recombinant human serotonin $_{5 A}$ receptors stably expressed in C6 glioma cells couple to multiple signal transduction pathways," Journal of Neurochemistry, vol. 84, no. 2, pp. 222-232, 2003.
[127] W. Wisden, E. M. Parker, C. D. Mahle et al., "Cloning and characterizatin of the rat $5-\mathrm{HT}_{5 \mathrm{~B}}$ receptor. Evidencie that the $5-\mathrm{HT}_{5 \mathrm{~B}}$ receptor couples to a $\mathrm{G}$ protein in mammalian cell membranes," FEBS Letters, vol. 333, no. 1-2, pp. 25-31, 1993.

[128] A. M. Kinsey, A. Wainwright, R. Heavens, D. J. Sirinathsinghji, and K. R. Oliver, "Distribution of 5-ht(5A), 5-ht(5B), 5-ht(6) and 5-HT(7) receptor mRNAs in the rat brain," Molecular Brain Research, vol. 88, no. 1-2, pp. 194-198, 2001.

[129] R. Grailhe, G. W. Grabtree, and R. Hen, "Human 5-HT receptors: the $5-\mathrm{HT}_{5 \mathrm{~A}}$ receptor is functional but the $5-\mathrm{HT}_{5 \mathrm{~B}}$ receptor was lost during mammalian evolution," European Journal of Pharmacology, vol. 418, no. 3, pp. 157-167, 2001.

[130] T. Maekawa, S. Kim, D. Nakai et al., "Social isolation stress induces ATF-7 phosphorylation and impairs silencing of the 5-HT 5B receptor gene," The EMBO Journal, vol. 29, no. 1, pp. 196-208, 2010.

[131] M. Ruat, E. Traiffort, J. M. Arrang et al., "A novel rat serotonin (5-HT6) receptor: molecular cloning, localization and stimulation of cAMP accumulation," Biochemical and Biophysical Research Communications, vol. 193, no. 1, pp. 268-276, 1993.

[132] M. Ruat, E. Traiffort, R. Leurs et al., "Molecular cloning, characterization, and localization of a high-affinity serotonin receptor (5-HT7) activating cAMP formation," Proceedings of the National Academy of Sciences of the United States of America, vol. 90, no. 18, pp. 8547-8551, 1993.

[133] U. Bickmeyer, M. Heine, T. Manzke, and D. W. Richter, "Differential modulation of $\mathrm{I}(\mathrm{h})$ by 5 -HT receptors in mouse CA1 hippocampal neurons," European Journal of Neuroscience, vol. 16, no. 2, pp. 209-218, 2002.

[134] L. Costa, C. Trovato, S. A. Musumeci, M. V. Catania, and L. Ciranna, "5-HT(1A) and 5-HT(7) receptors differently modulate AMPA receptor-mediated hippocampal synaptic trasnmission," Hippocampus. In press.

[135] S. R. Joca, F. R. Ferreira, and F. S. Guimaraes, "Modulation of stress consequences by hippocampal monoaminergic, glutamatergic and nitrergic neurotransmitter systems," Stress, vol. 10, no. 3, pp. 227-249, 2007.

[136] H. Schoemaker and S. Z. Langer, "[3H]8-OH-DPAT labels the serotonin transporter in the rat striatum," European Journal of Pharmacology, vol. 124, no. 3, pp. 371-373, 1986.

[137] K. P. Lesch and R. Mössner, "Genetically driven variation in serotonin uptake: is there a link to affective spectrum, neurodevelopmental, and neurodegenerative disorders?" Biological Psychiatry, vol. 44, no. 3, pp. 179-192, 1998.

[138] K. Sugden, A. Tichopad, N. Khan, I. W. Craig, and U. M. D'Souza, "Genes within the serotonergic system are differentially expressed in human brain," BMC Neuroscience, vol. 15, pp. 10-50, 2009.

[139] N. Nordquist and L. Oreland, "Serotonin, genetic variability, behaviour, and psychiatric disorders-a review," Upsala Journal of Medical Sciences, vol. 115, no. 1, pp. 2-10, 2010.

[140] K. Martinowich and B. Lu, "Interaction between BDNF and serotonin: role in mood disorders," Neuropsychopharmacology, vol. 33, no. 1, pp. 73-83, 2008.

[141] L. J. Siever, "Neurobiology of aggression and violence," American Journal of Psychiatry, vol. 165, no. 4, pp. 429-442, 2008.

[142] K. Waters, "Serotonin in the sudden infant death syndrome," Drug News and Perspectives, vol. 23, no. 9, pp. 537-548, 2010. 
[143] J. R. Moiseiwitsch and J. M. Lauder, "Serotonin regulates mouse cranial neural crest migration," Proceedings of the National Academy of Sciences of the United States of America, vol. 92, no. 16, pp. 7182-7186, 1995.

[144] J. M. Brezun and A. Daszuta, "Depletion in serotonin decreases neurogenesis in the dentate gyrus and the subventricular zone of adult rats," Neuroscience, vol. 89, no. 4, pp. 999-1002, 1999.

[145] J. M. Brezun and A. Daszuta, "Serotonergic reinnervation reverses lesion-induced decreases in PSA-NCAM labeling and proliferation of hippocampal cells in adult rats," Hippocampus, vol. 10, no. 1, pp. 37-46, 2000.

[146] L. Lanfumey, R. Mongeau, C. Cohen-Salmon, and M. Hamon, "Corticosteroid-serotonin interactions in the neurobiological mechanisms of stress-related disorders," Neuroscience and Biobehavioral Reviews, vol. 32, no. 6, pp. 11741184, 2008.

[147] S. Haj-Dahmane and R. Y. Shen, "Modulation of the serotonin system by endocannabinoid signaling," Neuropharmacology, vol. 61, no. 3, pp. 414-420, 2011.

[148] M. Banasr, M. Hery, J. M. Brezun, and A. Daszuta, "Serotonin mediates oestrogen stimulation of cell proliferation in the adult dentate gyrus," European Journal of Neuroscience, vol. 14, no. 9, pp. 1417-1424, 2001.

[149] H. Wang and D. R. Storm, "Calmodulin-regulated adenylyl cyclases: cross-talk and plasticity in the central nervous system," Molecular Pharmacology, vol. 63, no. 3, pp. 463-468, 2003.

[150] R. L. Djavadian, "Serotonin and neurogenesis in the hippocampal dentate gyrus of adult mammals," Acta Neurobiologiae Experimentalis, vol. 64, no. 2, pp. 189-200, 2004.

[151] P. R. Albert, B. le Francois, and A. M. Millar, "Transcriptional dysregulation of 5-HT1A autoreceptors in mental illness," Molecular Brain, vol. 4, no. 1, p. 21, 2011.

[152] U. Staubli and N. Otaky, "Serotonin controls the magnitude of LTP induced by theta bursts via an action on NMDAreceptor-mediated responses," Brain Research, vol. 643, no. 1-2, pp. 10-16, 1994.

[153] A. M. Gardier, "Mutant mouse models and antidepressant drug research: focus on serotonin and brain-derived neurotrophic factor," Behavioural Pharmacology, vol. 20, no. 1, pp. 18-32, 2009.

[154] R. Saxena and A. Chattopadhyay, "Membrane organization and dynamics of the serotonin1A receptor in live cells," Journal of Neurochemistry, vol. 116, no. 5, pp. 726-733, 2011.

[155] A. Schmitt, J. Benninghoff, R. Moessner et al., "Adult neurogenesis in serotonin transporter deficient mice," Journal of Neural Transmission, vol. 114, no. 9, pp. 1107-1119, 2007.

[156] R. S. Duman, G. R. Heninger, and E. J. Nestler, "A molecular and cellular theory of depression," Archives of General Psychiatry, vol. 54, no. 7, pp. 597-606, 1997.

[157] I. Hindmarch, "Beyond the monoamine hypothesis: mechanisms, molecules and methods," European Psychiatry, vol. 17, supplement 3, pp. 294-299, 2002.

[158] T. Sharp and P. J. Cowen, "5-HT and depression: is the glass half-full?" Current Opinion in Pharmacology, vol. 11, no. 1, pp. 45-51, 2011.

[159] R. S. Duman, "A silver bullet for the treatment of depression?" Neuron, vol. 55, no. 5, pp. 679-681, 2007.

[160] R. Corradetti, N. Laaris, N. Hanoun et al., "Antagonist properties of (-)-pindolol and WAY 100635 at somatodendritic and postsynaptic 5-HT1A receptors in the rat brain," British Journal of Pharmacology, vol. 123, no. 3, pp. 449-462, 1998.
[161] E. le Poul, C. Boni, N. Hanoun et al., "Differential adaptation of brain 5-HT1A and 5-HT1B receptors and 5HT transporter in rats treated chronically with fluoxetine," Neuropharmacology, vol. 39, no. 1, pp. 110-122, 2000.

[162] M. B. Passani, A. M. Pugliese, M. Azzurrini, and R. Corradetti, "Effects of DAU 6215, a novel 5-hydroxytryptamine3 (5-HT3) antagonist on electrophysiological properties of the rat hippocampus," British Journal of Pharmacology, vol. 112, no. 2, pp. 695-703, 1994.

[163] L. Hertz, "Neuronal-astrocytic interactions in brain development, brain function and brain disease," Advances in Experimental Medicine and Biology, vol. 296, pp. 143-159, 1991.

[164] S. Mouillet-Richard, V. Mutel, S. Loric, C. Tournois, J. M. Launay, and O. Kellermann, "Regulation by neurotransmitter receptors of serotonergic or catecholaminergic neuronal cell differentiation," Journal of Biological Chemistry, vol. 275, no. 13, pp. 9186-9192, 2000.

[165] P. M. Whitaker-Azmitia, "The role of serotonin and serotonin receptors in development of the mammalian nervous system," in Receptors in the Developing Nervous System, I. S. N. Zagon and P. J. McLaughlin, Eds., vol. 2, pp. 43-50, Chapman and Hall, London, UK, 1993. 

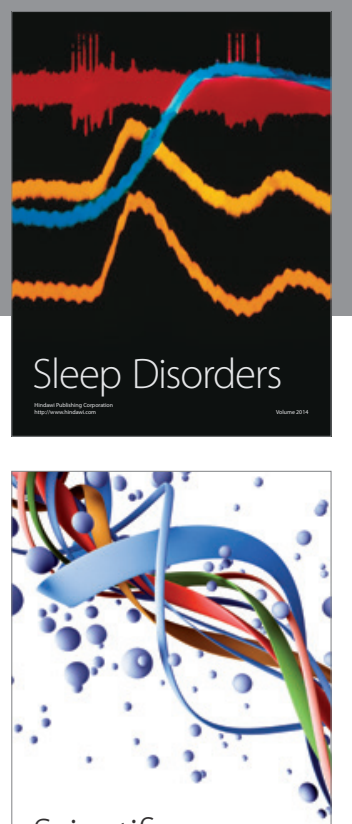

Scientifica
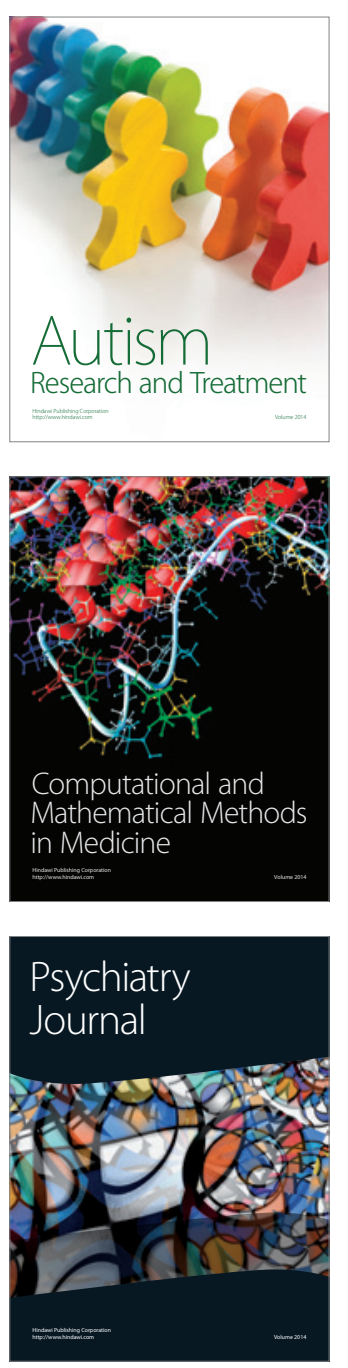
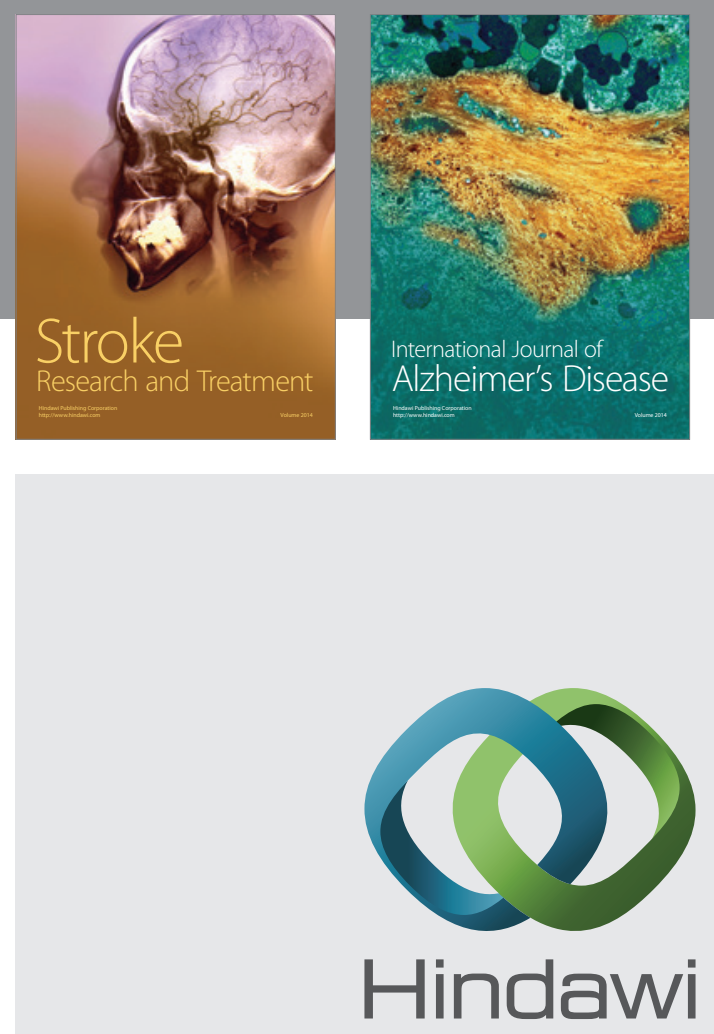

Submit your manuscripts at

http://www.hindawi.com
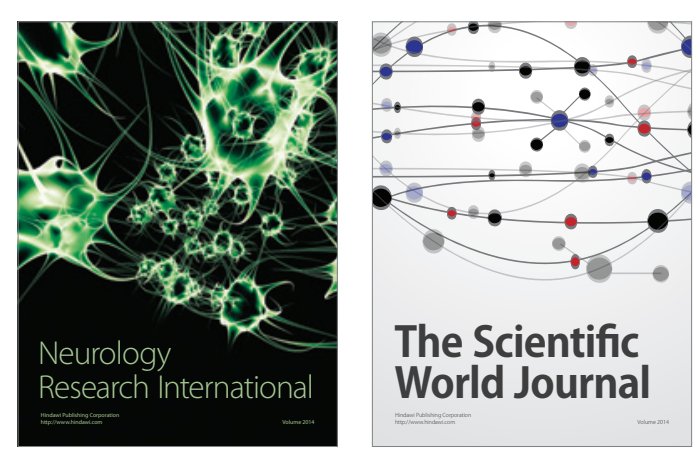

The Scientific World Journal

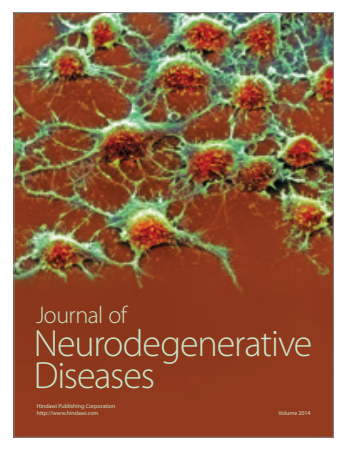

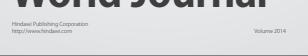

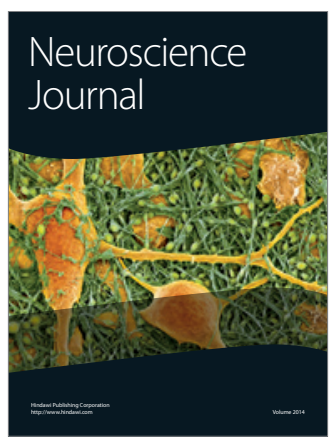

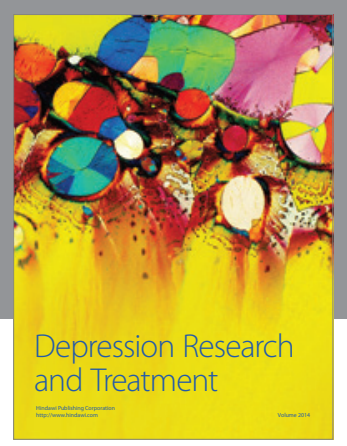
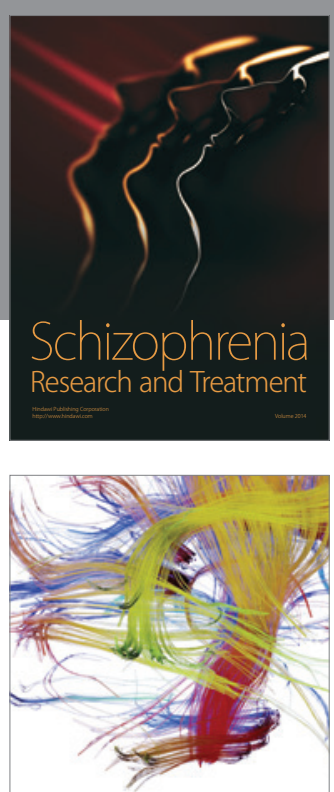

Brain Science

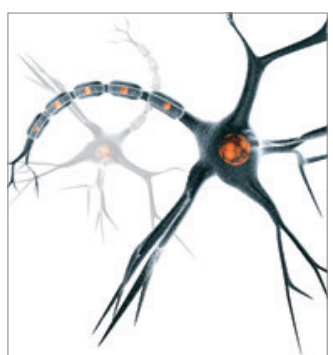

Neural Plasticity
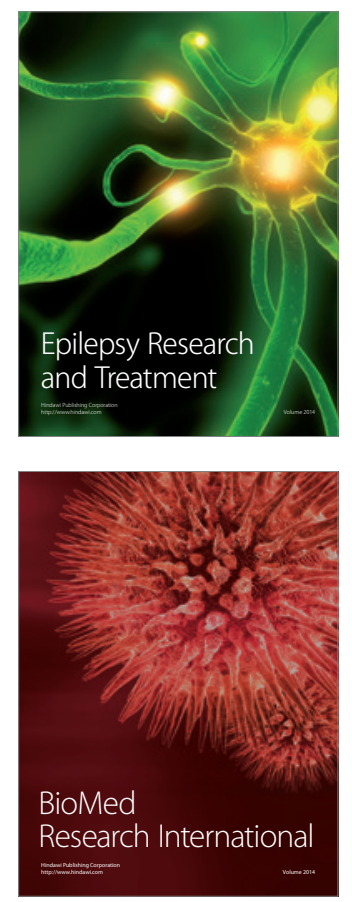

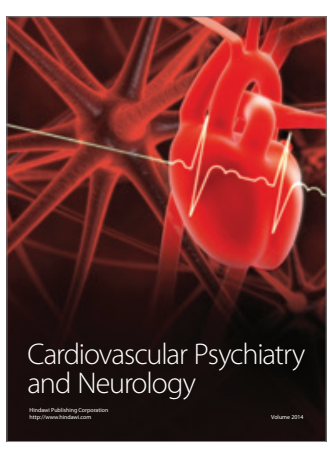

Parkinson's

Disease
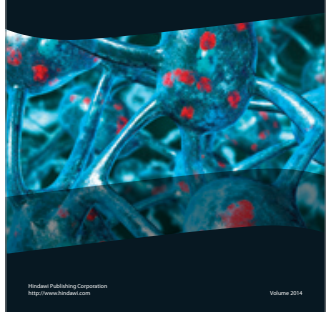